\title{
Denying the Secret of Joy: A Critique of Posner's Theory of Sexuality
}

\author{
Martha Ertman*
}

SeX AND ReAson. By Richard A. Posner. $\dagger$ Cambridge: Harvard University Press. $1992.458 \mathrm{pp}$. $\$ 29.95$.

\section{INTRODUCTION}

In Possessing the Secret of Joy, Alice Walker provides a fictional account of the crushing impact of genital mutilation on Tashi, an African woman of the Olinka tribe:

My own body was a mystery to me, as was the female body, beyond the function of the breasts, to almost everyone I knew. From prison Our Leader said we must keep ourselves clean and pure as we had since time immemorial-by cutting out unclean parts of our bodies. Everyone knew that if a woman was not circumcised her unclean parts would grow so long they'd soon touch her thighs; she'd become masculine and arouse herself. No man could enter her because her own erection would be in his way. ${ }^{1}$

Tashi's American husband, whose life was profoundly affected by Tashi's mutilation, tried to understand the ritual and proposed a possible explana-

* B.A., Wellesley College, 1985; J.D., Northwestern University School of Law, 1990. Associate, Davis Wright Tremaine, Seattle, Washington. I would like to thank Ian Ayres, Mary Becker, Nancy Ehrenreich, Jennifer Hertz, Charlie Piot, and Jon Waltz for their helpful comments on earlier drafts. I am particularly grateful for the insights and enthusiasm of Julie Nice.

$\dagger$ Judge, United States Court of Appeals for the Seventh Circuit; Senior Lecturer, University of Chicago Law School.

1. Alice WALKer, Possessing the SeCRET OF JoY 119 (1992). The fictional Olinka people justify mutilating the genitalia of their girls and young women with a creation myth which links female genital mutilation to the very formation of the earth:

The God Amma ... took a lump of clay, squeezed it in his hand and flung it from him, as he had done with the stars. The clay spread and fell on the north, which is the top, and from there stretched out to the south, which is the bottom, of the world, although the whole movement was horizontal. The earth lies flat, but the north is the top. It extends east and west with separate members like a foetus in the womb. It is a body, that is to say, a thing with members branching out from a central mass. This body, lying flat, face upwards, in a line from north to south, is feminine. Amma, being lonely and desirous of intercourse with this creature, approached it. This was the occasion of the first breach of the order of the universe. ...

At God's approach, the termite hill rose up, barring the passage and displaying its masculinity. It was as strong as the organ of the stranger, and intercourse could not take place. But God is all-powerful. He cut down the termite hill, and had intercourse with the excised earth. But the original incident was destined to affect the course of things forever....

Id. at 169. 
tion for it: "[P]erhaps it was to make sexual love between women impossible that men destroyed their external sexual organs." 2

Judge Richard Posner's Sex and Reason delves into the collective unconscious to articulate a theory of sexuality that closely resembles the ritual of the fictional Olinka people. In doing so, he neatly, even surgically, excises female sexuality from his theory. The resemblance between Tashi's experience and Posner's theory is not, however, immediately apparent. In Sex and Reason, Posner applies economic theory to sexuality by positing "an integrated biological-economic theory of sex ... [as] the most promising theory of the subject that we are likely to have for some time."3 Moreover, unlike Alice Walker, he focuses on Western histories of sexuality. Nevertheless, Posner's theory negates lesbianism as surely as genital mutilation does. ${ }^{4}$

Posner's failure to include female sexuality in his theory not only negates the feelings and experiences of lesbians, but also reveals numerous flaws in his reasoning. While surgical clitoridectomy may aim to make lesbianism practically impossible, Posner's theory renders lesbianism a logical impossibility. This gap in reasoning and analysis makes Sex and Reason, like Possessing the Secret of Joy, better fiction, albeit historical fiction, than theory or scholarship.

This review briefly describes Posner's synthesis of sociobiology and economics to form a bioeconomic theory of sexuality and summarizes Posner's discussion (or lack thereof) of lesbians. Three beliefs underlie Posner's scattered treatment of lesbians: (1) lesbians are few; ${ }^{5}$ (2) they are lesbian by choice rather than predisposition; ${ }^{6}$ and (3) they do not suffer discrimination on the grounds of their sexual orientation. ${ }^{7}$ This review contests these three beliefs and argues that, paradoxically, the same reasoning that Posner uses to negate lesbian existence, identity, and experience could also support a conclusion that all women are naturally lesbian. The facility with which Posner's theory supports contradictory conclusions indicates an underlying weakness in his bioeconomic theory of sexuality.

At first glance, it may seem irrational to pick out Posner's treatment of lesbians as a fatally weak link in his chain of logic. Posner rarely addresses lesbianism and lesbian sex in Sex and Reason. ${ }^{8}$ When he does include lesbi-

2. Id. at 177. This position has also been taken by Adrienne Rich, Compulsory Heterosexuality and Lesbian Existence, in Powers of Desire: The Politics of SeXuality 177, 185 (Ann Snitow, Christine Stansell \& Sharon Thompson eds., 1983) [hereinafter POWERS OF DESIRE] (citing KATHLeEN BARRY, Female SeXual Slavery 163-64 (1979)).

3. Pp. 7-8.

4. Reading a theory is undoubtedly less harmful than enduring mutilating surgery. Yet, the experience of reading Posner's theory, as a lesbian, is similarly shocking and numbing. The theory purports to encompass the world of human sexuality, and does much, but leaves crucial territory uncharted.

5. See notes 132-139 infra and accompanying text.

6. See notes 140-161 infra and accompanying text.

7. See notes 162-172 infra and accompanying text.

8. Posner lists 23 references to lesbians in the index of Sex and Reason (though I counted a total of 37 textual references to lesbians). In contrast, there are 140 entries in the index under "homosexuality" and "homosexuals." Strangely, there are only two entries in the index for "hetero- 
ans in his discussion, Posner negates lesbian existence, identity, and experience. It may seem unfair to criticize Posner for what he does not do, rather than what he does do. However, as Posner himself recognizes, "[t]extual silences can be pregnant." 9 His silence about lesbianism is particularly pertinent because he explicitly asserts that his theory includes all forms of human sexuality. ${ }^{10}$

Posner does discuss female heterosexuality and male hetero- and homosexuality, making his exclusion of lesbian sexuality an anomalous, yet salient, characteristic of his theory. He recognizes the profound impact of female gender and occupational status on sexuality. ${ }^{11} \mathrm{He}$ measures a society's attitude toward sexuality largely by its attitude toward male homosexuality. ${ }^{12}$ Yet even in these forays into the female and gay spheres, Posner's discussion is limited or flawed. For example, the term "homosexual" in Sex and Reason almost exclusively refers to gay men.13 Word choice alone, then, excludes lesbians from most of Posner's analysis. Moreover, Posner portrays women as interested in sex for reproduction or companionship, rather than for pleasure or other social goals. ${ }^{14}$ Posner's analysis of race and class is similarly flawed: He stereotypes the sexual incentives of AfricanAmericans and poor people. ${ }^{15}$ Taken together, these limitations indicate

sexuality" (with a cross reference to "homosexuality, opportunistic"). In addition, the 44 entries under "women" and the three entries under "female sexual pleasure" contrast with the absence of any index references to "men" or "male sexual pleasure" to reveal Posner's male-centered perspective. The sole entries regarding male sexuality are five references to "machismo" and two to "masculinity" (with a cross reference to "effeminacy"). Interestingly, there is no entry in the index for "femininity."

9. P. 142.

10. Posner sets out to "present a theory of sexuality that both explains the principal regularities in the practice of sex and in its social, including legal, regulation" and does not explicitly limit his analysis to male sexuality. Nor does he exempt lesbian sexuality from the category of "principal regularities." Pp. 2-3.

11. See, e.g., p. 39 (discussing the double standard for adultery among ancient Greeks); p. 86 (asserting that the occupational status of women is one factor in the variance of sexual behavior between men and women); see also pp. 171, 173-78, 195-96, 252, 259.

12. Pp. 60-64 (illustrating Posner's use of American society's homophobia as a measure of its attitude toward sexuality in general); see also p. 69 (arguing that Japanese tolerance of homosexuality is an indicator of liberal sexual mores). His focus on male sexuality may not be intentional, since, as he acknowledges, much historical scholarship systematically excludes women. See p. 27. Whether intentional or not, the omission weakens his theory.

13. See, e.g., p. 61 (discussing how homosexuality was uncommon in colonial America "[d]espite a shortage of women"); p. 64 (citing that some Americans believe "most homosexuals could be 'converted' to heterosexuality by sexually skilled women"); p. 66 (stating the perception that men who always adopt the "penetrating role," whether with women or other men, are not gay). Posner occasionally uses the terms "(male) homosexuality" and "male homosexual." See, e.g., pp. $304-05,307$. However, his overall concentration is on male homosexuality and his use of a supposedly gender neutral word to discuss solely men systematically excludes women from his analysis. Elementary feminist theory recognizes the congruity of sexist analysis with one term ("man") used to denote both all of humanity and males.

14. See notes 53 \& 205-207 infra and accompanying text.

15. See William N. Eskridge, Jr., A Social Constructionist Critique of Posner's Sex and Reason: Steps Toward a Gaylegal Agenda, 102 YALE L.J. 333, 360, 363 (1992) (book review); Gillian K. Hadfield, Flirting with Science: Richard Posner on the Bioeconomics of Sexual Man, 106 HARV. L. REv. 479, 491-92 \& nn.31, 33 (1992) (book review). In fairness, as mentioned in note 12 supra, historical scholarship has tended to focus on propertied men. 
that Posner is not writing about "human" sexuality, but rather about the sexuality of white, propertied men.

Several reasons militate exposing Posner's failure to adequately address lesbian sexuality. First, lesbians are both women and sexual minorities, and thus present a unique cross-section of gender and sexuality that is essential to any comprehensive discussion of sexuality. Second, despite Posner's contentions to the contrary, lesbians suffer discrimination on the basis of their sexual orientation, and have a history that is necessary to any inclusive discussion of human sexuality. ${ }^{16}$ Finally, if I am right that Posner's theory has excised female sexuality, it cannot plausibly account for the sexual love between women. Therefore, a lesbian critique of Sex and Reason can test potential weaknesses in Posner's theory of sexuality.

This review is just that, a review. Posner explores a staggering range of issues over centuries of discourse about sexuality. I do not attempt to replicate his research or analysis. Rather, I merely aim to provide insights on one narrow aspect of his work. Posner's stature as a jurist and scholar dictate wide and diverse debate about Sex and Reason. But Posner's prominence is both advantageous and dangerous: It guarantees needed public discourse questioning the often irrational regulation of sexuality; but it also makes it likely that Posner's sometimes questionable analysis and conclusions, despite their serious flaws, will be uncritically relied upon. The goal of this review, then, is to identify some of these flaws in the hope that other commentators will critically and knowledgeably participate in the sexual regulation debate.

\section{The InVisible Lesbian: Posner's Approach to The Theory AND HISTORY OF SEXUALITY}

Sex and Reason is divided into three parts: a review of the theoretical and historical foundations of sexuality; a statement of Posner's bioeconomic theory of sexuality; and an application of his theory to state regulation of sexuality.

16. A number of sources could have helped Posner in filling the gaps in his analysis. See, e.g., Allan Berube, Coming OUt UNDER Fire: THe History of Gay MEN aNd WOMEN IN WORLD WAR TWO (1990); JUDITH BROWN, IMMODEST ACTS (1986); VERN BUllough, HoMOSEXUALITY: A History (1979); CATHARINE VAN CASSElaER, LOT's WifE: Lesbian PARIS, 18901914 (1986); JoHN D'EMIlio \& Estelle B. Freedman, INTIMATE MATTERS: A History of Sexuality in America (1988); Rudolf M. DekKer \& LotTe C. van de Pol, The Tradition of Female Transvestism in Early Modern Europe (1989); Martin Duberman, About TiME: EXPLORING THE GAY PAST (1991); LILlian FADERMAN, ODD GIRLS AND TwILIGHT LOVERS (1991); Lillian Faderman, SuRPassing the LOVE OF MEN (1981); Judy GRAHN, ANOTHER MOTHER TONGUE: GAY WORDS, GAY WORLDS (1984); A. IDE, LOVING WOMEN: A HistoRY OF LESBIANISM TO 500 C.E. (1985); JOAN NESTLE, Lesbians and Prostitutes: An Historical Sisterhood, in A Restricted Country 157 (1987); Richard Plant, The Pink Triangle (1986); Hidden From History: Reclaiming the Gay and Lesbian Past (Martin Bauml Duberman, George Chauncey, Jr. \& Martha Vicinus eds., 1989) [hereinafter HIDDEN FROM HISTORY]; Allan Bérubé, Marching to a Different Drummer: Lesbian and Gay GIs in World War II, in POWERS OF DESIRE, supra note 2, at 88; A Lesbian Execution in Germany, 1721: The Trial Records (Brigitte Eriksson trans.), J. HoMOSEXUALITY, Fall/Winter 1980/1981, at 27. 


\section{A. Shaming the Judiciary: Posner's Goals and Theoretical Premises}

Posner bases his bioeconomic theory of sexuality on libertarian thought ${ }^{17}$ and emphasizes the "paramountcy of rational choice."18 Posner chose the topic of sex because it is "[a] major source of human pleasures and pains[,] ... of human institutions, of political controversy, perhaps even of the growth and decline of nations, [and] it deserves our best intellectual efforts." 19 His aims are fourfold: (1) "to bring to the attention of the legal profession the rich multidisciplinary literature on sexuality-and to shame [his] colleagues in the profession for ignoring it"; ${ }^{20}(2)$ "to demonstrate the feasibility and fruitfulness of an economic approach" to sexuality;21 (3) "to expound a specific economic theory of sexuality";22 and (4) "to use social scientific knowledge of sexuality, including the knowledge generated by economic analysis, as a foundation for proposing reforms in law and public policy."23

Posner intertwines sociobiology and economics into a bioeconomic theory of sexuality, purporting to encompass "the social, including the legal, implications of sex."24 Sociobiology identifies certain "biological realities" that supposedly dictate human behavior. ${ }^{25}$ Economic theory conceives of human beings as rational utility maximizers who make choices subject to external incentives, opportunities, and constraints. As applied to law, the theory calls for legal rules that achieve efficiency and the maximization of wealth. ${ }^{26}$

Posner theorizes that all sexuality is subordinate to the drive to reproduce. ${ }^{27}$ This drive to reproduce is informed by both the biological urge and the individual's rational interest in perpetuating his or her gene line. Toward these ends, men take extreme measures to ensure that they expend precious resources toward supporting only their biological children, rather than squandering resources supporting another man's gene line. This reasoning leads Posner to posit that people are overwhelmingly heterosexual because they are driven by the urge to procreate and continue their gene

17. P. 3. Posner uses libertarianism to mean the belief that "[g]overnment interference with adult consensual activities is unjustified unless it can be shown to be necessary for the protection of the liberty or property of other persons." P. 3.

18. P. 3.

19. P. 10.

20. P. 4.

21. P. 4.

22. P. 5.

23. P. 7.

24. P. 4.

25. Anne Fausto-Sterling, Myths of Gender: Biological Theories About Men AND WOMEN 156-62 (1985). Webster's defines sociobiology as "the comparative study of social organization in animals and [hu]man[s] esp[ecially] with regard to its genetic basis and evolutionary history." WEBSTER's NiNTH NEW CollegIaTE DictionARY 1119 (Frederick C. Mish ed., 1983).

26. See pp. 181-219 (Posner's chapter on the "Optimal Regulation of Sexuality").

27. See pp. 85-110 (Posner's chapter on "The Biology of Sex"). Posner distinguishes between "normal" sex for procreation or to reward the male for protecting the woman and children, p. 98, and "deviant" sex which is pursued when "normal" sex is unavailable. P. 99. 
pool, ${ }^{28}$ and that men must take extraordinary measures to control female reproduction to best accomplish this goal. ${ }^{29}$

Posner recognizes, though, that human sexuality encompasses more than mere procreative sex. In articulating his bioeconomic theory of sexuality, Posner analyzes the bioeconomic efficiency of numerous phenomena: homosexuality (under which Posner includes pederasty and pedophilia ${ }^{30}$ ), prostitution, pornography, rape, adultery, bigamy, infanticide, transvestism, and female genital mutilation. ${ }^{31}$ Posner's theory attempts to explain as economically efficient a double standard that privileges adultery by men and penalpool).

28. See, e.g., pp. $89-90$ (discussing optimal sexual strategies as those which diversify the gene

29. See, e.g., p. 94 (arguing that the man "who can monopolize a number of fertile females... is maximizing his genetic fitness"); p. 95 (arguing that the man's best strategy involves watching his women "like a hawk to make sure they are bearing his children").

30. Posner defines pederasty, the "sexual desire of adult men for adolescent boys" as distinct from "homosexual pedophilia, the sexual desire of adult men for boys who have not yet reached adolescence." P. 42. He recognizes that heterosexual men abuse children, referring to them as "normal" men seeking sexual substitutes for women. P. 400. He notes that one-third of child sexual abuse is by a relative and that studies have indicated that up to $25 \%$ of girls and $10 \%$ of boys are victims of sexual abuse and that most of the abusers are men. P. 399 \& n.46; see also CATHARINE A. MACKINNON, FEMINISM UNMODIFIED 41 (1987) (putting the figures at as much as $38 \%$ of girls and $10 \%$ of boys). He neglects, however, to note that a child, male or female, is more than 100 times more likely to be sexually abused by a heterosexual than by a gay man. See Carol Kreck, "Gays Not Sex Abusers, Study Says," Denv. Post, Sept. 28, 1992, at 8A.

31. Posner calls female genital mutilation "the surgical removal of the clitoris." P. 37. This clinical shorthand and his later analysis of female genital mutilation fail to account for the pain, shame, and life-long physical and mental scarring that results from "female circumcision," clitoridectomies, and infibulation. For example, he scientifically explains how genital mutilation preserves virginity in polygamous cultures:

By reducing the woman's capacity to experience sexual pleasure, the removal of the clitoris reduces the risk of a wife's committing adultery, a more serious risk in a polygamous than in a monogamous culture because the satisfactions of marriage to the wife are fewer. Infibulation [sewing up the entrance of the vagina] is a measure for ensuring virginity until marriage.

P. 257. Posner neglects to mention that infibulation in some cultures does not disappear after marriage. Moreover, at least one commentator has interpreted infibulation as a ritual of female fertility, rather than as a method for males to control female sexuality. JANICE BODDY, WOMBS AND ALIEN SPIRITS: Women, MEN AND THE ZAR CULT OF NorThern SUdAN 52-88 (1989); Janice Boddy, Womb as Oasis: The Symbolic Context of Pharaonic Circumcision in Rural Northern Sudan, 9 AM. ETHNOLOGIST 682 (1982). For recent legal commentary on the tension between cultural sensitivity and the protection of women, see Isabelle R. Gunning, Arrogant Perception, World Travelling and Multi-Cultural Feminism: The Case of Female Genital Surgeries, 23 ColUm. Hum. RTS. L. REv. 189 (1991-1992); Robyn Cerny Smith, Note, Female Circumcision: Bringing Women's Perspectives into the International Debate, 65 S. CAL. L. REV. 2449 (1992).

Alice Walker states:

It is estimated that from ninety to one hundred million women and girls living today in African, Far Eastern and Middle Eastern countries have been genitally mutilated. Recent articles in the media have reported on the growing practice of 'female circumcision' in the United States and Europe, among immigrants from countries where it is part of the culture.

WALKER, supra note 1, at 281. References which include the perspective of the circumcised woman, rather than the man benefiting from the circumcision include G.J. BARKER-BENFIELD, THE HOR-

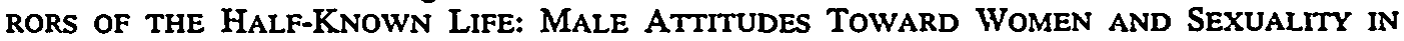
Nineteenth-Century America 120-32 (1976); Asma El Dareer, Woman Why Do You Weep? (1982); Hanny Lightfoot-Klein, Prisoners of Ritual: AN Odyssey into Female Genital Circumcision in Africa (1989). 
izes adultery by women, ${ }^{32}$ female infanticide, ${ }^{33}$ and prostitution. ${ }^{34}$

Although Posner has set laudable goals of educating the judiciary on sexuality and proposing reforms of current sexual regulations, he has, unfortunately, left holes in his reasoning that hobble his theory. He relies on questionable sociobiological theories, elevating bigotry to scholarship. Moreover, despite claiming to adopt a standard of "moral indifference," he privileges certain groups over others, often without explanation, and ultimately without justification. The intertwined relationship of sociobiology and moral judgment in the theory is evidenced by Posner's statement in another context, that "[p]erhaps morals wait on biology." 35

First, Posner's uncritical acceptance of sociobiological premises undercuts his theory. Many sociobiologists rely on research conducted only on male sexual development (neglecting the other half of humanity), which yields skewed results. ${ }^{36}$ Moreover, children's gender identity is far more flexible than the sociobiologists presuppose. ${ }^{37}$ Finally, sociobiologists' "claims about human nature [based on maximizing inclusive fitness] fall so far short of being scientifically defensible that one can only consider human sociobiology as a political science." 38 Posner's theory similarly focuses almost exclusively on male sexual desire, rigidifies gender roles, and reads more like a just-so story than a coherent theory explaining the breadth and complexity of human sexuality. His reliance on sociobiology thus limits his theory's applicability. ${ }^{39}$

Second, Posner fails to achieve his goal of "moral indifference." $\mathrm{He}$ adopts the goal of a "morally indifferent" model of sexuality as an ideal, citing the achievements of Sweden in this regard..$^{40}$ Certainly Northern European attitudes are more respectful of gay men and lesbians than many American attitudes, which favor intolerance and the continued economic, social, and political persecution of lesbians and gay men. ${ }^{41}$ Unfortunately,

32. Pp. 184-85.

33. Pp. 143-44.

34. Pp. 130-33, 186. Posner measures the costs of prostitution to a man's children against the benefits of prostitution to the prostitute and her customer. P. 186. He does not recognize the costs to the prostitute. For a study documenting the cost of prostitution to the prostitute, see KATHLEEN BarRy, Female SeXual Slavery (1984). Gillian Hadfield notes that when Posner discusses prostitution he neglects to analyze the implications of regulations and practices on women's lives. Instead, he focuses on male demand for prostitutes' services. Hadfield, supra note 15, at 500 .

35. P. 290. The context is determining when life begins for purposes of abortion law.

36. FAUSTO-STERLING, supra note 25 , at $61-88$.

37. Id.

38. Id. at 204. For further discussion of Posner's sociobiological premises, see notes 69-76 infra and accompanying text.

39. For further critiques of sociobiology, see FAusto-STERLING, supra note 25; MARSHALL Sahlins, The Use and abuse of Biology: AN ANThropological Critique of SociobiOLOGY (1976). See also Hadfield, supra note 15, at 487-91. For a critique of Posner's use of sociobiology in Sex and Reason, see Jane E. Larson, The New Home Economics (unpublished manuscript, on file with Stanford Law Review).

40. Pp. 441-42. Posner's theory would follow the Swedish model "[e]xcept that it would try to avoid subsidizing the production of illegitimate children." P. 201.

41. This intolerance is typified by the words of the United States Supreme Court, "To hold that the act of homosexual sodomy is somehow protected as a fundamental right would be to cast 
however, Posner's analysis contains moral judgment at every turn. He claims to free sexual discourse of its moral baggage by treating sexual practices as no more significant than eating. ${ }^{42}$ If he achieved his goal, then he would treat hetero- and homosexuality as equivalent to eating an apple or a carrot. Yet he gives preferences to heterosexuality over homosexuality in a way that is no more rational than a hypothetical constitutional ruling allowing the criminalization of fruit consumption, while forbidding any regulation of eating vegetables. ${ }^{43}$

For example, Posner assumes that vaginal-penile penetration, and the people who practice it, are natural and normal, while sex between partners of the same sex, and the partners themselves, are deviant. $44 \mathrm{He}$ also characterizes the "homosexual life-style" as a "distinctive, and to a significant degree, an unhappy one."45 Further, he expects parents to encourage their children to be heterosexual, even if the parents are gay or lesbian. ${ }^{46}$ Posner's use of terms such as "natural" and "deviant" reveals a moral position informing all his assumptions, notwithstanding his protestations that he uses

aside millennia of moral teaching." Bowers v. Hardwick, 478 U.S. 186, 197 (1986) (Burger, C.J., concurring) (upholding the constitutionality of Georgia's criminal sodomy statute as applied to gays).

42. Posner states: "I try to strip away the moral and emotional overtones, the preconceptions, the myths, the customary attitudes that make it difficult for people in our society, however well educated, to treat sex, and its regulation by law or social custom, as subjects of dispassionate scientific study." P. 85. The "morally indifferent" theory of sexuality would treat sexuality as equivalent to eating or driving. P. 85. For Posner's additional discussions of this concept, see p. 181 ("laissezfaire approach to sex"); p. 352 ("[o]nce again the analogy of eating is helpful"); p. 355-56 (focusing on the "formal properties" of an orgy depicted on a Greek vase as similar to those of a dance or a feast).

43. The United States Supreme Court has reached similar conclusions regarding sexual preferences in its Fourteenth Amendment cases. In Loving v. Virginia, 388 U.S. 1 (1967), the Court struck down restrictions on interracial marriage. In Eisenstadt v. Baird, 405 U.S. 438 (1972), it struck down regulations limiting access to contraception to heterosexual married couples. In Bowers v. Hardwick, 478 U.S. 186 (1986), it upheld the criminalization of consensual sodomy between gay men, while explicitly reserving the question of whether the statute passed constitutional muster if applied to heterosexual couples. Posner has incorporated this irrational preference for heterosexuals by, for example, stating that gay sodomy is "deviant" and heterosexual sodomy is "normal." $P$. 98 n.27.

Seven examples illustrate Posner's preferences for heterosexuality over homosexuality: (1) he classifies heterosexual sex as "normal" and gay sex as "deviant," p. 98; (2) he believes heterosexual and gay parents should encourage their children to be heterosexual, notes 181-182 infra and accompanying text; (3) he accommodates "public hostility to homosexuals" by advocating domestic partnerships rather than gay marriage, p. 313 ; (4) he defers to military and societal homophobia to conclude that the ban on gays in the military should not yet be lifted, pp. 318-21; (5) he states that parental rejection of gay children may be genetic, note 100 infra and accompanying text; (6) he says that gay teachers should not be entitled to protection from employment discrimination if their presence might encourage a bisexual student to come out as gay (Posner apparently has no similar concerns about heterosexual teachers swaying bisexual students toward being heterosexual), p. 404 (suggesting that it is efficient to allow gays to teach if they do not "inveigle children into the homosexual life," and as long as allowing gays to teach does not cause "heterosexual fight" akin to "white flight"); and (7) he disparages the American Psychological and American Public Health Associations for "pretend[ing]" in their amicus curiae brief for Bowers that "homosexuals and their relationships are just like heterosexuals and their relationships," p. 346.

44. P. 98.

45. P. 303.

46. See notes $186-193$ infra and accompanying text. 
these terms in a nonpejorative fashion. ${ }^{47}$

Posner's failure to discuss lesbianism adequately reveals the weaknesses of his sociobiological and moral premises. He marginalizes women's sexuality by limiting it almost entirely to the accommodation of male sexual needs and procreation. ${ }^{48}$ If Posner is right, then no woman would seek sex with another woman, because lesbian sex neither satisfies male sexual needs nor leads to procreation. Since all lesbians are women who have sex for reasons beyond the scope of Posner's analysis, Posner's theory fails to explain or even allow for lesbianism. Lesbians, however, do exist and they are sexual with other women. The discrepancy between theory and reality suggests that Posner's theory fails, at least in part, because it cannot explain sexual love between women.

\section{B. From Greece to Griswold: Posner's History of Sexuality}

Posner first purports to summarize the history of human sexuality, beginning with ancient Greece and Rome. ${ }^{49}$ In this discussion, he addresses homosexuality, but limits it to pederasty. Posner argues that homosexuality as we define it today did not exist. According to Posner, men did not choose same-sex activity for life; instead, young men of the citizen class had sexual relations with boys only until women of comparable class were available for marriage. In other words, Posner argues that same-sex activity among Greek citizen men was a function of their late marriage age, which resulted in the need for young men as substitutes for the "real article," women. He distinguishes between "real" gays and "opportunistic" gays, because "[t]o the ancient Greeks . . . the male sex drive, as expressed in phallic penetration, is more important than the sex object."50 Posner repeats this distinction between "real" and "opportunistic" gays tirelessly throughout Sex and Reason. ${ }^{51}$ Finally, he notes that although the ancient Greeks had a permis-

47. Posner claims to use the term "deviance" without pejorative connotations, to describe a departure from the statistical norm. See p. 106. He parenthetically mentions that he might use the terms "substitute" or "peripheral sexuality" because they are "less charged with normative significance." P. 106. However, he ignores that gay and lesbian sex are neither substitute nor peripheral for lesbians and gay men, and in any case he continues to use the term "deviant" throughout the remainder of Sex and Reason. Further, because Posner defines "normal sex" as "vaginal intercourse designed either to produce offspring or to reward the male for protecting the offspring already produced," p. 98, heterosexual sex with birth control prior to the birth of any children arguably is "deviant" under Posner's definition. Yet the participants likely do not perceive it as "substitute" or "peripheral." Finally, Posner himself admits the importance of word choice in fashioning a message; he deliberately uses the term "homosexual" rather than "gay," apparently for fear of being responsive to the political demands of lesbians and gay men. Pp. 292-93.

48. Posner defines "normal sex" as heterosexual intercourse for reproduction or to reward the male for protecting children. P. 98. This definition focuses on motive to determine normalcy, excluding female pleasure as a motive. Indeed, Posner believes "nature has encouraged reproduction by making sex a continual desire of $m e n$, the satisfaction of which is intensely pleasurable independent of any procreative motive." P. 97 (emphasis added). But see pp. 111-15 (discussing hedonistic and social ends of sex); $c f$. p. 113 (noting that satisfying sex may cement or jeopardize heterosexual relationships by making the woman "more susceptible to the advances of other males").

49. Pp. 38-45.

50. P. 24.

51. Posner acknowledges that sexuality probably falls along a continuum from heterosexual to 
sive view of sexuality for citizen men, they nevertheless disapproved of lesbians and despised male recipients of anal intercourse. ${ }^{52}$

Posner's survey of antiquity underscores his focus on male object choice throughout Sex and Reason. He perceives the history of sexuality as the history of male sexual object choice: A man is heterosexual if he chooses a woman and gay if he chooses a man. In contrast, Posner excludes female sexual experiences from the discussion by positing that women choose partners not for sex, but rather, companionship. ${ }^{53}$ Posner thus treats man as subject and woman as object. He focuses on what men want now and have wanted historically from sex, and notes only occasionally the impact of male desires on women. Posner almost never inquires into what women want from sex. ${ }^{54}$ His limited vision also excludes lesbian sexuality. ${ }^{55}$ For exam-

homosexual, pp. 105-06, and generally refers to those individuals one would expect to find midway on the continuum as "opportunistic homosexuals." Posner seems to doubt the existence of genuine bisexuals; I could find only two instances where he referred to "bisexuals" rather than "opportunistic homosexuals". See p. $141 \mathrm{n} .69$ (discussing how some individuals labelled gay may only be "opportunistic homosexuals (hence 'really' heterosexual), or genuine bisexuals, rather than 'real' homosexuals"); pp. 105-06 (stating, without explanation, that he uses the term "opportunistic homosexual" where others use the term "bisexual" because he finds "bisexual" a "confusing usage"). In one discussion of opportunistic gays, Posner provides a definition that captures his meaning of the term: "a bachelor whose access to females is highly restricted." P. 148. For further discussion of "real" versus "opportunistic" homosexuality, see pp. 128, 147, 158, 163, 179, 233. Posner further clarified his disbelief in bisexuality in an interview with U.S. News and World Report:

The literature on homosexuality contains compelling documentation that there's a distribution of preference among men. Some are strongly heterosexual and not interested in a male substitute for a female. At the other end of the spectrum are the exclusively homosexual males. But in between there are basically heterosexual men who will substitute males for females.

Alvin P. Sanoff, The Economics of Sex, U.S. NEWS \& WoRLD REP., May 4, 1992, at 61 (emphasis added).

Posner is trying to appropriate self-identified gays into the heterosexual population, which may explain the basis of Posner's criticism of the Kinsey statistic that $10 \%$ of adult Americans are gay or lesbian. Pp. 128, 294. Posner contests Kinsey's figure of $10 \%$ because it included the $6 \%$ of men who were gay for three or more years with the $4 \%$ of the population who were exclusively gay. Instead, Posner prefers to lump the three year gay population with the heterosexuals, which leaves just $4 \%$ of the male population gay and $1 \%$ or $2 \%$ of the female population lesbian. The problem with Posner's classification is that it includes as heterosexuals people who have same-sex sex over years of their lives.

52. P. 42 .

53. P. 91 (" $[I] t$ is plausible to expect natural selection against a powerful sex drive in women. ... There is much evidence that women do in fact have (on average, of course, not in every case) a weaker sex drive than men."). Posner's lack of attention to whatever meager sex drive a female might have is reflected in his assumption that heterosexual women crave male companionship, while heterosexual men seek heterosexual opportunities. See pp. 137, 152 (explaining lesbianism in polygynous households, and gay male sex aboard naval vessels).

54. Posner's sole references to women in classical antiquity imply that women had no sexual desire. His analysis covers the limitations on sexual conduct of the wives and daughters of citizen men. P. 39. Moreover, it completely ignores any sexual freedom, or lack thereof, accorded to the female prostitutes, dancers, concubines, and slaves who provided the sexual variety enjoyed by the citizen men. For a more complete discussion of the sexuality of women in classical antiquity, see SaRAh B. Pomeroy, Goddesses, Whores, Wives, and Slaves: Women in Classical antiQUITY 86-88, 88-92, 113-14, 142-48 (1975) (sexual experiences); id. at 114-17, 139-41, 201-02 (prostitution); id. at 53-56, 144-45 (homoeroticism); id. at 81-82, 86-87, 103-05, 128-29, 159-60 (adultery).

55. Posner states:

Greek tolerance for homosexuality did not extend to lesbianism, which the Greeks thought unnatural and revolting .... The Greeks' antipathy to lesbianism can be understood as a 
ple, Posner fails to discuss Sappho, the lesbian poet and philosopher, even as he discusses in detail ancient Greek men's views toward male sexuality. ${ }^{56}$ By treating all Greek society as equivalent to propertied, male Greek society, Posner leaves out a significant part of the population and thus tells only part of the story of that society's sexuality. ${ }^{57}$

Posner next traces the regulation of sexuality through the "Era of Catholic Hegemony"58 and the Reformation, noting that in 1806, England executed more persons for committing sodomy than for murder. ${ }^{59}$ He discusses Western Europe's impact on American history, stating that except for abandoning capital punishment for sodomy, the Puritans retained the European laws regulating sexuality. ${ }^{60}$ Posner also mentions the Victorian view that homosexuality and other "sexual deviance" were "manifestation[s] of mental illness" rather than, as in earlier times, expressions of a criminal will.61

With the advent of the sexual revolution, Posner observes that even though "noncoercive deviant sexual acts, such as . . . homosexual activity between consenting adults. ... remain prohibited, ... the prohibited behavior may actually be flaunted."62 Despite this apparent tolerance, Posner describes modern American sexual norms, such as "very broad disapproval of homosexuality" and ignorance about sex, as conservative. ${ }^{63}$ Posner contrasts American views with the sexual mores of non-Western cultures. $\mathrm{He}$ characterizes Islamic society as less sexually repressive than Christianity, in

corollary of their phallocentrism. Normal sexuality for the Greeks placed male desire at center stage, leaving no room for sexual activity lacking a male participant.

P. 43. The Ancient Greek focus on male desire is echoed in Posner's own analysis. He deemphasizes female sexual desire by arguing that it was selected out in the evolutionary period, p. 91, and defines normal sex as "[penile/]vaginal intercourse" for reproduction or rewarding the male for protecting children. P. 98. Neither reproduction nor rewarding the male requires female sexual desire. Thus, Posner's most basic premises ignore or actively disparage the existence of female sexual desire.

56. That the very word "lesbian" stems from Sappho's home, the island of Lesbos, highlights this omission. See Webster's Third New InTERnational Dictionary 1296 (1961); $c f$. GRAHN, supra note 16, at 172-73 (noting that in the city of Mytilene on the island of Lesbos, Sappho "taught daughters sent to her from far-off lands, schooling them in the arts and graces and values suitable to the older matriarchal ways"). For a further discussion of Sappho, see RUTHANN RoBSON, LESBIAN (OUT)LAW 23 (1992) ("lesbian philosophers like Sappho have bequeathed us fragments of desire, while (gay) philosophers like Plato have left tomes discussing versions of the just society in lengthy dialogues with titles like 'Laws' and 'The Republic' "). See also SAPPHO AND THE GREEK LYRIC POETS 265-300, 273 (Willis Barnstone trans., 1988) (reconstructing Sappho's life and work from the surviving fragments of her poetry and references to her in antiquity, but rejecting as unsupported the theory that Sappho ran "a young lady's academy of manners").

57. For more extensive treatment of male homosexuality in Ancient Greece and Rome, see John Boswell, Revolutions, Universals, and Sexual Categories, in HIDDEN FROM HISTORY, supra note 16, at 17, and David M. Halperin, Sex Before Sexuality: Pederasty, Politics and Power in Classical Athens, in HIDDEN FROM HISTORY, supra note 16, at 37. These articles respectively argue that homosexuality existed in Ancient Greece, and that sexuality as a social construct defining character did not exist prior to the twentieth century.

58. P. 45.

59. P. 52.

60. Pp. 60-61.

61. P. 54.

62. P. 56.

63. P. 64. 
that it tolerates (male) homosexuality. ${ }^{64}$ Again, however, Posner apparently overlooks lesbians in his discussion. ${ }^{65}$

Finally, Posner baldly asserts that "although almost everywhere abhorred, lesbianism has rarely been criminalized."66 To support this statement, he cites the treatment of lesbians by the Ancient Greeks and the Nazis in Germany, and notes that English common law did not outlaw lesbianism. ${ }^{67}$ Many scholars, who have painstakingly researched the systematic and brutal persecution of lesbians throughout history, no longer accept this once popular conclusion. ${ }^{68}$

\section{The Mixed Marriage of Sociobiology and Economics}

Despite Posner's claim that the reader need not agree with the premises of sociobiology to agree with his bioeconomic theory, ${ }^{69}$ both sociobiology and economics are essential elements of his theory. The centrality of sociobiology to Posner's bioeconomic theory stands out in his discussion of rational reproductive behavior during the evolutionary era. He posits that in the evolutionary era, men were primarily interested in maintaining a gene line, ${ }^{70}$ and women were primarily interested in finding men who would protect them and their children. ${ }^{71}$ Therefore, because men could father more children than women could gestate, ${ }^{72}$ polygynous arrangements satisfied

64. P. 67.

65. Pp. 66-69. Lesbianism does exist in non-European cultures. See Robin MORGAN, SISTERHOOD Is GLOBAL (1984) (discussing the tradition of woman-to-woman marriages among various peoples of Nigeria, the Northern Transvaal, parts of East Africa, and the Sudan); Paula Gunn Allen, Lesbians in American Indian Cultures, in HIDDEN FROM HISTORY, supra note 16, at 106 (discussing lesbianism in Native American cultures).

66. P. 70.

67. P. 70.

68. See, e.g., RoBson, supra note 56, at 29-45; Louis Crompton, The Myth of Lesbian Impunity: Capital Laws from 1270 to 1791, J. HoMOSEXUALITY, Fall/Winter 1980/1981, at 11; Theo van der Meer, Tribades on Trial: Female Same-Sex Offenders in Late Eighteenth-Century Amsterdam, in ForbidDEN History: THE STATE, SOCIETY, AND THE REgUlation OF SEXUALITY IN MODERN EUROPE 189 (John C. Font ed., 1992); Ruthann Robson, Lesbianism in Anglo-American Legal History, 5 WISC. WOMEN'S L.J. 1, 21-40 (1990). For additional sources documenting and analyzing lesbian history, see note 16 supra.

69. P. 110.

70. Pp. 88-98. Therefore, Posner concludes "a man's best sexual strategy is promiscuity." P. 95.

71. P. 95. Posner describes the evolution of a woman's desires as follows:

A woman who wants to maximize her reproductive success must be charier of her sexual favors than a man. She must try to make every pregnancy count: every pregnancy, ideally, must have a reasonable probability of producing a child that will survive to adulthood. So, especially in the evolutionary period, when life was precarious, a woman had to be intensely concerned about the quality of her mate as a potential father.

P. 91. Posner continues this analysis to conclude that female sexual desire is based on these same considerations: "We expect [a woman] to be aroused by cues related to the male's likely ability to protect her and her offspring." P. 93.

72. Posner reasons that:

The male has a vast potential reproductive capacity because his only absolutely indispensable role in reproduction is to inseminate the female, a task of minutes ... and because he can play the role with great frequency without substantial sperm depletion. The reproductive capacity of the individual female is so much more limited . . . that a male cannot realize his full reproductive potential with a single sex partner. 
both the need of the man to know that his children were his, ${ }^{73}$ and the woman's desire that her children live to reach reproductive age. ${ }^{74}$ Posner hypothesizes that this sociobiological economic story remains relevant today because human emotions were formed in the evolutionary era. ${ }^{75}$

Sociobiological theory studies the basis for genetic changes in human evolutionary history and focuses on reproductive motivations for sex. Posner adopts this focus and accordingly Posner's theory assumes that heterosexuality is "normal" and homosexuality is "deviant."76 By emphasizing procreative sex and the continuation of the species, Posner treats heterosexuality as the only form of "normal" sex. Even assuming that heterosexual intercourse is the sole means of human reproduction (which it no longer is, through reproductive technologies such as artificial insemination), that fact does not inevitably lead to heterosexual social organization. As one commentator has noted, "[t]his assumption of female heterosexuality seems to me to be in itself remarkable: it is an enormous assumption to have glided so silently into the foundations of our thought."77 Thus, social organization could be totally independent of the biological kinship of the father; women could live and love together and have occasional sex with men for reproductive purposes only.

Posner's analysis suggests rather implausibly that the process of breeding and the emotional and logistical processes of living are inextricable. As Posner himself acknowledges, however, the actual act of insemination requires mere minutes. ${ }^{78}$ These few minutes hardly require a lifetime of living together. People are sexual for many reasons other than reproduction, such as emotional and physical pleasure. Indeed, Posner himself spends a great deal of energy attempting to explain nonprocreative sex within his assumption of procreation as the sexual norm. ${ }^{79}$

P. 90.

73. "The male who can monopolize a number of fertile females-that is, can exclude other males from sexual access to them so that he can be confident that his women's children are his-is maximizing his genetic fitness, provided he can protect his offspring." P. 94. The man will watch these women "like a hawk to make sure they are bearing his children, lest he waste costly protective efforts perpetuating another man's genes." P. 95.

74. Posner applies this reasoning to define what he calls "normal" or "procreative-protective sex":

to denote vaginal intercourse that rewards the male for staying with the female, and by doing so increases the likelihood that the female will survive to the end of her fertile years and that her children will survive till they reach their fertile years and beyond, so that their children will survive to adulthood too. Note that anal and oral sex, when heterosexual, can be procreative-protective, hence not "deviant" as I use that term here.

P. 98 n.27 (emphasis in original).

75. P. 185 (suggesting that human emotions are adapted to conditions of the evolutionary era of human prehistory).

76. Chapter Four, "The Biology of Sex," pp. 85-110, divides the discussion between "The Biological Basis and Character of "Normal' Sex," where Posner discusses "procreative-protective" sex, pp. 88-98, and "The Biology of 'Deviant' Sex," in which he investigates the biological bases for sex which is not procreative (e.g., masturbation, homosexuality, voyeurism, exhibitionism, seduction of young children, and fetishism). P. 98-108.

77. Rich, supra note 2 , at 182 .

78. P. 90.

79. But see pp. 111-15 (discussing the hedonistic and associative benefits of sex). However, 
For instance, rather than acknowledge that his theory cannot account for homosexuality, Posner argues that male homosexuality was an adaptive response of weak men who could not fight off stronger men to establish a polygynous household. ${ }^{80}$ Moreover, Posner extinguishes lesbian possibilities by positing a "natural selection against a powerful sex drive in women," so that women now have "a weaker sex drive than men."81 While deemphasizing female sexual interest in men, he all but ignores female sexual interest in other women. The unexpressed assumption is that most women are naturally heterosexual. ${ }^{82}$ Thus, women in Posner's theory are naturally heterosexual, the operative element of that word being "hetero-" rather than "sexual."

Under Posner's theory, lesbianism is deviant, but unlike male homosexuality, it is not biological. Posner argues instead that along with women's sex drive, lesbian preference was, for the most part, "selected out" during the evolutionary era. ${ }^{83}$ Under Posner's theory, lesbianism is a double negative. If women do not have a sex drive, other than to procreate, and lesbians are women who have sex with other women, then the very existence of lesbianism, and lesbian passion, is a logical impossibility. Thus, it is not surprising that Posner's theory cannot adequately account for lesbianism. Paradoxically, an alternative logical extreme of Posner's theory makes all women naturally lesbian. ${ }^{84}$

Posner's description of his bioeconomic theory of sexuality culminates with a brief review of the moral theories of sexuality and of sex radicals. In his discussion of sex radicals, Posner lists only men, most of whom wrote forty to ninety years ago. ${ }^{85}$ Notably absent from the discussion are hetero-

Posner implies that the hedonistic element of heterosexuality could be trumped by the procreative, since the woman's sexual pleasure might make her susceptible to other men's advances, and thus jeopardize her mate's desire to protect her and her offspring. See p. 113.

80. Posner reasons that if there are equal numbers of men and women, and the strong man is sexual with many women, then there will be men left over. P. 99. He supposes that "because of some congenital hormonal abnormality a small percentage of male children are born somewhat deficient in characteristic male attributes such as boldness and aggressiveness (or they may simply be small and weak), and the deficiency will make them when mature relatively unattractive to women." Pp. 102-03 (footnote omitted).

81. P. 91.

82. In the alternative, Posner could be proposing that women have no sexual orientation. That reading of Posner's theory, however, may be too complete an erasure of female sexuality given the other references Posner makes to women.

83. P. 99. Posner's argument that lesbianism tended to be selected out in the evolutionary era presupposes a female sex drive that was sacrificed (if in fact it ever existed) to serve the needs of procreation and protection of offspring. See notes 48 \& 53 supra. Despite his statement that the sex drive of women is "on average," rather than universally, lower than men's, p. 91 n.8, he does not remedy this limitation to his analysis by discussing women who have high sex drives. Moreover, rather than analyzing the purportedly lower female sex drive (or exploring whether women have higher preferences for non-coital sexual activities than men, on average), Posner proceeds through the bulk of his analysis as if female sexual drive is limited to interests in procreation and retaining a man's protection, rather than the pursuit of pleasure for its own sake. See notes 48 \& 53 supra.

84. See notes 205-260 infra and accompanying text.

85. Pp. 237-40 nn.36-45. In his discussion, Posner cites William F. Edmiston, Diderot aNd the Family: A Conflict of Nature aNd LAW (1985); Herbert Marcuse, ERos aND Civilization: A Philosophical INQuiry into Freud (1955); Wilhelm Reich, The Sexual 
sexual women and lesbians. A more comprehensive and representative catalogue of sex radicals might include Emma Goldman and Anais Nin, writers and advocates of free love at the turn of this century; ${ }^{86}$ Camille Paglia, controversial social commentator and scholar; ${ }^{87}$ Susie Bright, author and publisher of lesbian erotica; ${ }^{88}$ and Pat Califia, writer and commentator. ${ }^{89}$

\section{There Oughta Be a Law Against It: Regulating Sex}

Posner next applies his theory to analyze the efficiency of sex regulations, devoting chapters to policy questions regarding homosexuality, ${ }^{90}$ judicial decisions regarding sexual privacy, ${ }^{91}$ and coercive sex. ${ }^{92}$ Throughout the discussion of legal issues, policy questions, and sexual privacy, Posner makes assertions or assumptions regarding gay men and lesbians that are remarkable in their display of ignorance or insensitivity. For example, in his chapter on coercive sex, Posner inexplicably includes a section on lesbians and gays as teachers under the subheading "Sexual Abuse of Children."93 Posner's focus on concerns about gay teachers molesting children is misplaced. He should be more concerned about heterosexual male contact with children, since children are in fact more likely to be molested by a heterosexual man than by a gay man or lesbian. ${ }^{94}$ Yet he never suggests that heterosexual men should be banned from teaching.

Revolution: Toward a Self-Governing Character Structure (1945); Bertrand RusSell, Marriage and Morals (1929); Bertrand Russell, The Problems of Philosophy (1912); Lars Ullerstam, The Erotic Minorities (1966); and MaX Weber, The Protestant ETHIC AND THE SPIRIT OF CAPITALISM (Talcott Parsons trans., 1958).

One commentator notes that despite Marcuse's trenchant analysis of social norms and sexual pleasure, he almost entirely ignores gender. Introductory comments to Anne Bobroff, Russian Working Women: Sexuality in Bonding Patterns and the Politics of Everyday Life, in Powers OF DESIRE, supra note 2, at 206. Posner's failure to account for female perspectives is perhaps explained in part by his choice of sources.

86. See, e.g., Emma Goldman, Living My Life (Dover Publications, Inc. 1970) (1931); ANAIS NIN, LITTLE BIRDS (1979).

87. See, e.g., Camille Paglia, Sex, Art, and American Culture (1992); Camille Paglia, SeXual Personae: ART aNd DeCADENCE from Nefertiti to Emily Dickinson (1990).

88. See, e.g., SUSIE Bright, SUSIE Bright's Sexual Reality: A Virtual SEX World Reader (1992); Susie Bright, Susie SeXPert's Lesbian SeX World (1990); Herotica: A COLlection of WOMEN's ERotic Fiction (Susie Bright ed., 1988); Herotica 2: A COLleCTION OF WOMEN's ERotic Fiction (Susie Bright \& Joani Blank eds., 1991). Until recently, Ms. Bright also published On Our Backs, an erotic periodical "for the adventurous lesbian."

89. See, e.g., Pat Califia, Sapphistry: The Book of Lesbian Sexuality (3d ed. rev. 1988); see also AN INTIMATE WILDERNESS: LESBIAN WRITERS ON SEXUALITY (Judith Barrington ed., 1991).

90. Pp. 291-323.

91. Pp. 324-50. Posner discusses Griswold v. Connecticut, 381 U.S. 479 (1965), Roe v. Wade, 410 U.S. 113 (1973) (recognizing fundamental right to make reproductive decisions), pp. 324-41, and Bowers v. Hardwick, 478 U.S. 186 (1986) (upholding state law criminalizing consensual adult sodomy between men), pp. 341-50, as the parameters of what kinds of sexual privacy have been judicially protected under the Constitution, and what kinds have not.

92. Pp. 383-404.

93. Pp. 395, 403-04. Posner concludes this section by arguing that gay men and lesbians should be allowed to teach unless they "inveigle children into the homosexual life" or cause "heterosexual fight." P. 404.

94. See Kreck, supra note 30, at 8 A (noting that a child, male or female, is 100 times more likely to be sexually abused by a heterosexual than by a gay man). 
Even more glaring, Posner concludes that even "when every legal disability of homosexuality has been dismantled and every heterosexual has been thoroughly schooled in tolerance, the homosexual life-style" will still be "an unhappy one." 95 Posner's sole authority for this extraordinary conclusion that gays and lesbians are inherently unhappy is a letter from the Dutch military attache in the United States to openly gay Congressperson Gerry Studs regarding gays and lesbians in the Dutch military. ${ }^{96}$

Posner does not offer any additional support for his belief that gay men and lesbians are basically unhappy. There is, however, much evidence to the contrary. For example, psychologists' findings that gays and lesbians are as psychologically healthy as their heterosexual counterparts contradict Posner's conclusions. ${ }^{97}$ If happiness is instead measured by economic and professional success, the gay and lesbian population, with between $\$ 400$ billion and $\$ 514$ billion in annual earnings and a higher average level of education than their heterosexual counterparts, should be pretty cheerful. ${ }^{98}$ Moreover, happiness is certainly dependent on more variables than sexuality.

By whatever criteria Posner might apply to measure happiness, gay men and lesbians are capable of the same happiness as their heterosexual counterparts. Unfortunately, the greatest source of unhappiness in the lives of many lesbians and gay men is rejection by their families. ${ }^{99}$ Rather than advocating

95. P. 303. Posner continues:

[E]ven in a tolerant society the life prospects of a homosexual-not in every case, of course, but on average-are, especially for the male homosexual, grimmer than those of an otherwise identical heterosexual, a conclusion that lends an ironic touch to the appropriation of the word gay to mean 'homosexual' - usually male homosexual.

P. 307 (emphasis in original).

96. The letter reads in part: "[A]lthough until now there are no known structural problems about the functioning of homosexuals in the armed forces it has to be considered that most of the homosexuals make a secret of their sexual orientation out of fear for reactions." P. 307. Posner finds this letter persuasive because the Netherlands is "decades ahead of the United States in tolerance of homosexuality." P. 307. He apparently reasons that gays will always be unhappy because, despite the progressive attitudes of the Dutch, gays in the Netherlands still fear public reaction.

Nothing in the letter, however, suggests misery among gays and lesbians. To the contrary, it merely suggests that homophobia persists in the Dutch military despite recent efforts to protect gays and lesbians from discrimination in its ranks. Moreover, research has long indicated that there is no difference between heterosexuals and gays in their social adjustment and mental health. See, e.g., Evelyn Hooker, Male Homosexuality in the Rorschach, 22 J. ProJeCTIVE TECHS. 33 (1958); Evelyn Hooker, The Adjustment of the Male Overt Homosexual, 21 J. Projective Techs. 18 (1957).

97. Indeed, "[i]n 1973, the American Psychiatric Association removed homosexuality from the list of psychiatric disorders and, in 1975, the American Psychological Association urged all mental health professionals to remove the stigma of mental illness long associated vith a homosexual orientation." Paul Gibson, Gay Male and Lesbian Youth Suicide, in 3 RePORT OF THE SECRETARY's TASK FORCE ON YOUTH SUICIDE 3-115 (U.S. Department of Health and Human Services ed., 1989) (on file with the Stanford Law Review); see also Claire M. RenzetTi, Violent Betrayal: ParTNER ABUSE IN LESBIAN RELATIONSHIPS 27-28 (1992) (noting that several studies indicate that lesbians have more androgynous gender identities than heterosexual women, and other studies characterize androgyny as mentally healthy).

98. Stuart Elliot, $A$ Market That's Educated, Affuent and Homosexual, N.Y. TimEs, Sept. 23, 1992, at C3; Markie Robson-Scott, Gay Magazines Gloss over Financial Straits, SUNDAY TimES (London), May 10, 1992, §4, at 5.

99. See, e.g., Gibson, supra note 97, at 3-112; Louise RAFkin, Different DaUGhters (1987); Sherry Zitter, Coming Out to Mom: Theoretical Aspects of Mother-Daughter Process, in LESBIAN PsYchologies 177 (Boston Lesbian Psychologies Collective ed., 1987). One study of young 
an end to this estrangement, Posner suggests that parental rejection of gay and lesbian children may be genetically based. ${ }^{100}$ Moreover, by offering helpful hints to prevent a child from becoming gay or expressing a gay sexual orientation, he perpetuates attitudes that will ensure the continuation of such familial rejection. ${ }^{101}$

Posner also reviews current regulatory and legal disabilities imposed on gays, including criminalization of sodomy, the exclusion of gays from the military, failure to recognize gay and lesbian marriages, and discrimination in housing and employment. ${ }^{102}$ Although Posner asserts that these impediments have "limited significance," 103 he nevertheless recommends that: (1) sodomy laws should be repealed; 104 (2) registered partnerships offer an "intermediate solution" to gay marriages (which, although cost justified, are barred by public hostility); ${ }^{105}$ (3) the military should retain its bar against the recruitment of gays and lesbians, but should allow gays and lesbians to remain in the military once they enlist; ${ }^{106}$ and (4) gays and lesbians should be protected against employment discrimination in some jobs (pursuant to Title VII of the Civil Rights Act of $1964^{107}$ ), provided that heterosexuality remains a bona fide occupational qualification for other jobs. ${ }^{108}$

Perhaps Posner's groundless belief that gays and lesbians are irremedia-

gay males found that fully half experienced "negative parental response" in response to their sexual orientation, and $26 \%$ of the young men sampled were forced to leave home because of this parental rejection. Gibson, supra note 97 , at 3-112. Consequently, as much as $25 \%$ of the adolescent street population is lesbian or gay. Id. at 3-114. According to the U.S. Department of Health and Human Services, family problems, particularly familial rejection because of sexual orientation, is "probably the most significant factor in youth suicide." Id. at 3-127.

100. Posner notes the argument that "the strong antipathy of most parents toward a child's turning out to be homosexual suggests that homosexuality rarely if ever promotes inclusive fitness." P. 102. Shortly thereafter, Posner indicates agreement with that argument when he states that the "father's and mother's reactions (which may well be genetically programmed) to the incipient homosexual child steer him into a homosexual life pattern." P. 103 (emphasis added). This apparently genetic parental homophobia is expressed by coldness and distance from the gay child. Pp. 103-04.

101. Pp. 308-09 ("There is a bare chance that the formation of homosexual preference can be prevented by discouraging gender-nonconforming behavior at its outset (later is too late).") (emphasis in original).

102. Pp. 291-92.

103. P. 292.

104. P. 309.

105. P. 313. Registered partnerships are municipal recognitions of same sex couples and have been adopted in several U.S. cities. Vada Berger, Domestic Partnership Initiatives, 40 DEPAUL L. REV. 417, 419 (1991).

106. Pursuant to Posner's proposal, gays and lesbians would not be discharged if they have made the initial entry into the service with their sexual orientation undetected. For the sexual orientation to remain hidden, however, the gay or lesbian individual when enlisting would have to lie on the application. Under Posner's reform, therefore, a lesbian who got into the military by initially disguising her sexuality could still conceivably be discharged for lying. P. 321; see also NAN D. Hunter, Sherryl E. Michaelson \& Thomas B. Stoddard, American Civil Liberties Union, The Rights of Lesbians and Gay Men: The Basic ACLU Guide to a Gay Person's RIGHTS 37 (3d ed. 1992) (discussing discharge for fraudulent enlistment, i.e., lying about homosexuality in enlistment application).

107. 42 U.S.C. $\S 2000$ (e) (1988).

108. P. 322. In the private sector, however, Posner doubts the efficiency of laws forbidding discrimination. P. 323 (citing Richard A. Posner, The Efficiency and Efficacy of Title VII, 136 U. PA. L. REv. 513 (1987)). 
bly unhappy leads to these reluctant concessions on behalf of gays and lesbians. By relying on and perpetuating this stereotype, Posner once again negates the purported "moral indifference" in his theory; he succeeds only in elevating groundless stereotypes and bigotry to the level of scholarship.

\section{When BaD Things Happen to BAD Theory}

\section{A. Fighting Words}

Posner's linguistic choices reveal his exclusionary focus on male sexuality, a weakness of his theory. First, Posner uses the generic male pronoun throughout Sex and Reason when referring to the general (male and female) population, ${ }^{109}$ with noted exceptions of references to prostitutes or sterilization. ${ }^{110}$ Second, he uses the term "homosexual" to describe gays. While "homosexual" may be a clinically accurate way to refer to gays and lesbians, it reflects the kind of contempt that would be apparent in a contemporary commentator's description of African-Americans as "negroes" or female jews as "jewesses." Rather than employ the term "gay," which has been chosen by the people he discusses, Posner uses "homosexual," perhaps in an effort to distance himself from being perceived as responsive to gays and lesbians' "increasing political assertiveness."111 Finally, Posner conflates

109. See, e.g., pp. 46-48, 88, 102 n.38, 103, 119, 124, 164, 187, 225, 227, 354, 373-74, 378, 385.

110. See, e.g., p. 86 (the reader); pp. 209, 229 (prostitutes); p. 116 (sterilization).

111. P. 292. Posner explains more fully:

The limited significance of the legal disabilities imposed on homosexuals is shown by their increasing political assertiveness. Like other minority groups they have become a political force to be reckoned with, particularly in the cities in which they form a substantial fraction of the population. Few politicians dare nowadays to express outright antagonism to homosexuals; and in the arts world, the academy, the professions, the mass media, and other influential sectors of American society, criticism of homosexuality or homosexuals is almost as taboo as criticism of blacks, women, or Jews. The term homophobe, properly reserved for persons with a pathological fear or hatred of homosexuals, is now, like racist, an epithet apt to be bestowed on anyone who so much as questions the most extreme claims made on behalf of homosexuals. Homosexuals have persuaded many heterosexuals to refer to them by their preferred term, gay, a word from the argot of the homosexual subculture. Advocates for homosexuals have also been rather successful in convincing the American people both that homosexuals are far more numerous (10 percent of the adult population) than appears to be the case (probably no more than 3 percent) and that AIDS is a threat to everyone (rather than to discrete classes of the population, prominently including male homosexuals) and therefore that the federal government should lavishly subsidize efforts to discover a cure.

Pp. at 292-93 (emphasis in original).

Contrary to Posner's perception that homophobia is politically unpopular, the 1992 Republican National Convention was anti-gay, focusing on so-called family values. See Andrew Rosenthal, The 1992 Campaign Issues-Family Values; Bush Tries to Recoup from Harsh Tone on Values, N.Y. Times, Sept. 21, 1992, at Al; see also Joseph P. Shapiro, The True State of Gay America, U.S. NEws \& WORLD REP., Oct. 19, 1992, at 39. In November 1992, Colorado amended its state constitution. The amendment provides that no state entity shall accord protection from discrimination to gay men, lesbians, or bisexuals. George de Lama, States Take Pulse on Morality, CHI. TriB., Nov. 5, 1992, news $\S$, at 7. Although Colorado is enjoined from enforcing the amendment as this book review goes to press, the state has appealed the injunction. Evans v. Romer, 1993 WL 19678 (Colo. Dist. Ct.), appeal filed Jan. 19, 1993. Finally, President Clinton's actions to lift the ban on gays and lesbians in the military caused a national outcry of homophobic resistance. See R.W. Apple, Jr., Challenges from a Headstrong Public: Rebuking the Powerful on Baird and Gay Ban, N.Y. TIMES, 
"homosexual" with gay men. ${ }^{112}$ Use of the male-gendered pronoun, in addition to using "homosexual" to describe exclusively gay men, creates an analytic world devoid of lesbians. These factors suggest a treatment of lesbians that can only be characterized as dismissive.

Posner also perpetuates stereotypes. One cannot always tell whether Posner relies on stereotypes or is merely reciting them, since he fails to refute them and repeats some of them to explain his bioeconomic conclusions. Thus, he seems to agree with at least some of them. Although Posner might argue that he merely recites common perceptions and misperceptions, he has a duty as a scholar to either critique the stereotypes or provide support for them if he relies on them. Posner's words betray an insidious bias against gays, lesbians, and others. In agreeing with these stereotypes, Posner succeeds only in elevating bigotry to scholarship. He should have scrutinized these stereotypes carefully, and followed through on their implications.

For example, Posner repeatedly reinforces the stereotyped effeminacy of gay men and mannishness of lesbians. ${ }^{113} \mathrm{He}$ suggests that homosexuality may be caused by fathers rejecting effeminate sons, who in turn redirect af-

Jan. 29, 1993, at A1; Peter Applebome, Homosexual Issue Galvanizes Conservative Foes of Clinton, N.Y. TIMES, Feb. 1, 1993, at A1.

112. See, e.g., pp. 29-30, 119, 127, 157, 164, 197, 224, 300-02, 305, 309 n.47, 436. But see pp. 127, 141, 291 (making distinctions between male and female homosexuality). Examples of Posner's apparent assumption that "homosexual" refers exclusively to gay men include the following statements: "Despite a shortage of women in America during the colonial period, ... homosexuality appear[s] to have been uncommon," p. 61; and "most homosexuals could be 'converted' to heterosexuality by sexually skilled women." P. 64. While some writers refuse to use gender neutral language on the grounds that "man embraces woman," this witty justification is inappropriate to lesbians and gay men. Gay men do not embrace lesbians, at least not in the sense that linguistic sexists intend men to embrace women.

113. Posner claims that he does not use the term "effeminacy" in a pejorative way. P. 122. However, he discusses heterosexual objections to the "homosexual life-style," which seem to focus on the purported effeminacy of gay men:

The objection is to an entire homosexual life-style, involving what are believed to be characteristic demeanors, behaviors, attitudes, destinies that the heterosexual (and no doubt many a homosexual) abhors: a life-style believed to be pervaded with effeminacy, including physical weakness and cowardice; with promiscuity and intrigue, prominently including seduction of the young; with concentration in a handful of unmanly occupations centered on fashion, entertainment, decoration, and culture-such occupations as the theater (above all the ballet) and the arts, hairdressing, interior decoration, women's fashions, ladies' shops, library work; with furtiveness and concealment; with a bitchy, gossipy, histrionic, finicky, even hysterical manner; with a concern with externals (physical appearance, youth, dress); with bad health, physical and mental, including suicide and alcoholism; with a wretched old age; with a general immorality and unreliability; with an above-average IQ, education, and income (qualities that make homosexuals even more threatening, more insidious, more seductive and manipulative); and, of course, with narcissism.

Pp. 300-01 (citations omitted). Although Posner purports to compile this laundry list of unsavory stereotypes of gay men from the belief systems of homophobic heterosexuals, he does little, if anything, to refute any of them. To the contrary, he describes gay men and lesbians as fundamentally miserable, and gay men as effeminate. See p. 307 (discussing the unhappiness of gays, especially gay men); pp. 26, 66, 68, 103, 121-23, 126, 150-51, 300-02, 304, 315 (describing gay men as effeminate). $\mathrm{He}$ also uses the purported effeminacy of gay men to minimize military discrimination against gay men and justify his middle ground position on the military persecution of gays and lesbians, arguing that "the artistic, often effeminate homosexual who is most likely to have a problem of psychological adjustment is least likely to find the military an attractive career." P. 315.

In his thorough review of Sex and Reason from a gay male perspective, William Eskridge dis- 
fections to mothers and identify in "other than typically male terms." $114 \mathrm{He}$ further argues that because they are unattractive to women, effeminate men engage in more gay sex than noneffeminate men. ${ }^{115} \mathrm{He}$ also identifies a shortage of "real" men in the gay community, but hypothesizes that effeminacy may be a mechanism for signalling for partners rather than innate. ${ }^{116}$ Finally, according to him, "it is generally the effeminate homosexuals who are creative, artistic, histrionic, who ... give the homosexual style of life its distinctiveness."117 Posner's lesbians, on the other hand, are the "opposite of effeminate." 118 To him, their mannishness makes lesbians better suited for the military than gay men or heterosexual women. ${ }^{119}$ Moreover, Posner posits that lesbianism is "either a second-best choice by 'mannish' women who are unattractive to men or a political choice by angry feminists." 120

Gays are not the sole victims of Posner's casual generalizations-poor people and African-Americans are also subject to stereotyped treatment in Sex and Reason. He suggests that public assistance in the form of Aid to Families with Dependent Children increases the incidence of AIDS because by subsidizing illegitimacy, it reduces the benefits of contraception, and therefore, the use of condoms. ${ }^{121}$ Moreover, he states that "the social safety net stimulates nonmarital sexual activity by men as well as by womenanother link between socialism and promiscuity."122 Posner further observes that

with so favorable an effective sex ratio, black men (outside of prison) will be less likely than white men to engage in opportunistic homosexual behavior or to patronize prostitutes but more likely to have multiple sex partners, to be initiated into sex early, and to father illegitimate children, tendencies that make black men seem more promiscuous than white men. ${ }^{123}$

Finally, he opines that "men in these poor communities, in part because of their own poverty and in part because of the availability to them of multiple sex partners, tend not to be good providers." 124

When one critically examines these stereotypes, Posner's theory loses

cusses these stereotypes in detail, Eskridge, supra note 15, at 359-65 \& nn.140-169, and notes that they reflect a "pre-Kinsey, even a pre-Freud, approach to homosexual behavior," id. at 360.

114. P. 103.

115. Pp. 121-23.

116. Pp. $150-51$.

117. P. 304 (footnote omitted). Posner refers to gay men's effeminacy in numerous other contexts. See, e.g., p. 26 (social antipathy to effeminate gay men based on objection to masquerade); p. 66 (effeminate men "despised" in macho societies); p. 68 ("effeminate" berdaches honored in American Indian culture); p. 126 (smaller market of sex partners for effeminate men); pp. 300-02 (effeminacy's "undoubtedly" pejorative overtones may be due to intolerance or anxiety about gender generally).

118. P. 304.

119. P. 315.

120. P. 295. But see pp. 295-300 (recognizing that theories and evidence reviewed elsewhere in Sex and Reason strongly support the position that "real" homosexuality, especially male homosexuality, is biologically determined and not a matter of choice).

121. P. 115.

122. P. 185.

123. P. 138.

124. P. 167. 
strength. For example, it is simply inaccurate that all or even most lesbians are either too ugly to find male companions or are angry feminists. On the contrary, many lesbians are feminine, many have left marriages with men to form lesbian relationships, and many do not identify as feminists. ${ }^{125}$ Moreover, many gay men are masculine, bold, and aggressive, characteristics that Posner reserves for heterosexual men. ${ }^{126}$ Finally, although Posner conflates the categories of poor people with African-Americans, most poor people are non-hispanic whites, rather than African-Americans as Posner implies. ${ }^{127}$ Posner's use of these stereotypes suggests, at best, profound naiveté.

Ironically, Posner himself provides the best criticism for his focus on the purported effeminacy of gay men: Only 40 percent of gay men have some effeminate mannerisms. ${ }^{128}$ Posner does not elaborate whether "some" effeminate mannerisms might include an interest in the theater, or artistic abilities (which many heterosexual men also exhibit). ${ }^{129}$ However, even assuming that the twenty-year-old study he cites could be replicated with a contemporary gay male cohort, the fact remains that Posner has placed tremendous emphasis on a characteristic exhibited by, at most, less than half of the gay male community. ${ }^{130}$ These stereotypes are more than fighting words and ignorant generalizations; they contribute to the extraordinarily high rate

125. The danger of stereotypes such as these is not that they are never true, but rather that they are not always true. Margarethe Cammermeyer illustrates this point. She was chief nurse of the Washington Army National Guard until she was discharged from the military in 1992 after 26 years of distinguished service because she is lesbian. In contrast to Posner's claim that the "mannishness" of lesbians makes them good soldiers, p. 315, Ms. Cammermeyer describes herself as "an old married lady with kids." She is "a straight-laced woman in a beautiful magenta dress, a soldier, a mother and a nurse. The only thing that makes her different is her choice of lovers." Linda Keene, Attention! Nurse, Mom, War Hero, Margarethe Cammermeyer Speaks Out for 200,000 Gays and Lesbians in the Military, Seattle Times/Seattle Post-Intelligencer, Jan. 3, 1993, (Magazine) at 10, 14. Contrary to stereotypical assertions that most lesbians are either too mannish to get a male partner or are radical feminists who hate men, Ms. Cammermeyer was " 6 feet of striking beauty [when she joined the military]. She had high cheekbones, blue eyes, and a confident smile. Men noticed her." Id. at 15. Finally, rather than being unable to get a man, she left her husband to come out as a lesbian. Id.

Posner himself admits that numerous other lesbians, like Margarethe Cammermeyer, left their husbands to come out as lesbians. P. 417 (more than a third of a sample of San Francisco lesbians surveyed in 1970s had been married to men). Moreover, many lesbians are not feminist, just as many feminists are not lesbian. Finally, there is some authority that contrary to an amorphous mass of "mannish" women, some lesbians identify as "femme," rather than "butch." See generally, JoAnn loulan, The Lesbian ERotic Dance: Butch Femme ANdrogyny and Other Rhythms (1990); The Persistent Desire: A Butch Femme Reader (Joan Nestle ed., 1992).

126. One survey of 4,000 gay men and lesbians contradicts Posner's stereotypes of gay male hairdressers. It found that "more homosexuals work in science and engineering than in social services; $40 \%$ more are employed in finance and insurance than in entertainment and the arts; and ten times as many work in computers as in fashion." Thomas A. Stewart, Gay in Corporate America, FORTUNE, Dec. 16, 1991, at 42, 43. A comprehensive analysis of gender roles and identity is, however, beyond the scope of this review.

127. Robert Pear, Ranks of U.S. Poor Reach 35.7 Million, the Most Since '64, N.Y. TIMES, Sept. 4, 1992, at A1, A10.

128. P. 304 (citing Marcel T. Saghir \& Eli Robins, Male and Female HomosexualITY: A COMPREHENSIVE INVESTIGATION 106-07 (1973)).

129. For a list of his other stereotypes of gay men, see note 113 supra.

130. For a discussion of the damaging impact of stereotypes of gay men and lesbians as, respectively, effeminate and mannish, see Gibson, supra note 97, at 3-117 to 3-118. 
of gay teenage suicide by maintaining a cultural climate that encourages gay teens to internalize homophobic feelings and despair of ever finding love or living a happy, productive life. ${ }^{131}$ Moreover, they bely Posner's supposed "moral indifference."

\section{B. Lesbianism in Three Acts}

Posner maintains three beliefs about lesbians. First, there are few lesbians. Second, unlike their male counterparts, lesbians are not born to their orientation, but rather choose it. Third, these few women are not disadvantaged by law. His beliefs negate lesbian existence, identity, and experience and reduce lesbian concerns to a cipher.

\section{The incredible shrinking lesbian population.}

Posner disputes the common belief that 10 percent of the general population is gay or lesbian, and posits a lesbian population of no more than 1 percent of all women. ${ }^{132}$ Posner arrives at his figure primarily from the Kinsey study, noting that "[o]nly 13 percent of the women in the Kinsey sample had had at least one homosexual experience involving orgasm, compared to the 37 percent figure for men." 133 Posner fails to heed Kinsey's caution: "It cannot be emphasized too often that orgasm cannot be taken as the sole criterion for determining the degree of satisfaction which a female may derive from sexual activity." 134 Moreover, Kinsey found that 28 percent of women experience sexual attraction to other women, 19 percent act on these attractions, and 13 percent reach orgasm as a result of these contacts. ${ }^{135}$ Posner mistakes the number of women who have an orgasm in their samesex sexual encounters for the number of potential lesbians.

Posner also neglects to consider that between 10 percent and 40 percent of the women in the Kinsey sample did not experience orgasm in their heterosexual relationships. ${ }^{136}$ Therefore, under Posner's orgasm standard, at least 10 percent and up to 40 percent of the female population is not heterosexual. If these women are neither real nor opportunistic lesbians, then it seems that nearly half of the female population in Posner's world lacks a

131. In 1980, the American Psychiatric Association published a new edition of the Diagnostic and Statistical Manual of Mental Disorders (DSM III), which listed a new disorder called "egodystonic homosexuality." This disorder is evidenced by gay people who feel anxious and guilty about being gay, and yearn to be heterosexual. It is caused by internalization of negative feelings about homosexuality, and may be alleviated when the person accepts his or her sexual orientation "[with the help] of a supportive homosexual subculture." Gibson, supra note 97, at 3-118 to 3-119; see also notes 189-193 infra and accompanying text.

132. Pp. 128, 294-95.

133. P. 294 (footnote omitted).

134. Alfred C. Kinsey, Wardell B. Pomeroy, Clyde E. Martin \& Paul H. Gebhard, INSTITUTE FOR SEX RESEARCH, INDIANA UNIVERSITY, SEXUAL BEHAVIOR IN THE HUMAN FEMALE 371 (1953).

135. Id. at 453-54.

136. Id. at 382-84. Fully $10 \%$ of women in Kinsey's sample had not experienced orgasm in heterosexual marital relationships, even after fifteen years of marriage. Id. at 383. 
sexual orientation entirely. This methodology reveals Posner's dismissive treatment of female sexuality.

Posner also concludes that lesbianism is indeed less common than male homosexuality, relying, in addition to Kinsey's figures, ${ }^{137}$ on data that only one-fifth of the same-sex couples who availed themselves of Denmark's registered partnership law were lesbians. ${ }^{138}$ This conclusion completely overlooks alternative explanations. For example, fewer lesbians may have registered their partnerships because of strong opposition, on feminist grounds, to mimicking oppressive aspects of heterosexual marriage. ${ }^{139}$

\section{She made the bed, she can sleep in it.}

Posner apparently believes that lesbianism is a matter of choice rather than genetic predisposition. He recognizes that there are two contrasting viewpoints on the genesis of lesbianism: (1) it "is biologically determined"; or (2) it is "either a second-best choice by 'mannish' women who are unattractive to men or a political choice by angry feminists."140 Although he states that given the discrimination visited on gay men and lesbians, "the idea that millions of young men and women have chosen it ... seems preposterous," 141 Posner seems to prefer the choice theory regarding lesbians. $\mathrm{He}$ reasons that any genetic basis for "lesbian preference would have tended to be selected out" in the "evolutionary era." 142 Posner states that this era "apparently was characterized by a high degree of interpersonal violence, [and having] additional male protectors may well have done more for a child's chances of survival than to have additional female protectors."143 Posner also asserts that "[t]he rarity of lesbianism among animals" negates a genetic explanation of lesbianism, supporting his sociobiological theory. ${ }^{144}$ Therefore, assuming lesbians are made rather than born, Posner expects "opportunistic homosexuality to be more common among women than among men, at least relative to 'real' homosexuality." 145

137. Pp. 294-95.

138. P. 314 n.51.

139. See, e.g., Paula Ettlebrick, Since When Is Marriage a Path to Liberation?, 6 OuT/LooK 9 (1989); cf. RoBson, supra note 56, at 124-27 (arguing against lesbian emulation of the marriage model of relationships). But see Tom Stoddard, Why Gay People Should Seek the Right to Marry, in LESBIAN AND GAY MARRIAGE (Suzanne Sherman ed., 1992).

140. P. 295.

141. P. 297.

142. P. 99. To buttress this claim, Posner notes that "the twin evidence does not support a genetic theory of lesbianism." P. 102. He cites one study and acknowledges that it based its conclusions on only four sets of female twins. P. 102 n.40.

143. P. 102 (footnote omitted).

144. P. 101 n.34. Contrary to this assertion, Kinsey observed lesbian behavior in other species including rats, mice, hamsters, guinea pigs, rabbits, porcupines, martens, cattle, antelope, goats, horses, pigs, lions, sheep, monkeys, and chimpanzees. KINSEY ET AL., supra note 134, at 449. In some species, female-to-female sexual contacts are as common as male-to-male sexual contacts. Id. But see id. at 450 n.6 (noting that while exclusive but usually temporary male homosexuality has been observed in monkeys, lions, baboons, porpoises, and porcupines, "[n]o exclusively homosexual patterns have been reported for female mammals") (emphasis added).

145. P. 179. 
However, he is not clear as to what women are choosing when they choose to be lesbian. He does state that because women are generally less sexual than men, lesbians will have sex less frequently than both heterosexual and gay men. ${ }^{146}$ But Posner does not articulate what lesbians do when they have sex. He fleetingly refers both to lesbian "intercourse"147 and to "lesbian simulacra of intercourse such as the penetration of the vagina by an artificial penis." 148 While numerous writers have discussed the breadth of lesbian sexual activities, ${ }^{149}$ Posner fails to describe any other specific activities when he discusses lesbian sex. This absence is particularly notable when contrasted with the way he uses his renowned research skills to explore gay male sexuality and heterosexuality. In particular, he details penile/anal penetration, fellatio, and cunnilingus among both heterosexuals and gay men.150

Because Posner believes that lesbianism is not genetic, he concludes that "lesbian activity is likely to be even more responsive to a shifting pattern of benefits and costs." 151 According to Posner, one of the benefits of lesbianism is avoiding sexual abuse and harassment by men. Posner speculates that radical feminists who recognize that "sexual intercourse is easily viewed by men as an assertion of male dominance" or women who dislike men may "become practicing lesbians."152 Polygynous arrangements, "in which women are persistently deprived of male companionship," also foster this type of "opportunistic" lesbianism. ${ }^{153}$ These statements highlight Posner's view of male homosexuality and lesbianism, and thus of men and women: Men are sexual with other men only when "deprived of heterosexual outlets,"154 and women are sexual with other women when they are "deprived of male companionship."15s Thus, according to Posner, women are interested in companionship rather than heterosexual sex, and men are interested in sex, rather than companionship.

Contrary to Posner's assertions, even if there are fewer lesbians than gay men, the number of lesbians does not indicate whether the phenomenon is genetically linked. For example, there are few redheads, but the rarity of the

146. Posner states that "lesbian couples have intercourse less frequently, on average, than heterosexual couples do, while male homosexual couples have intercourse more frequently than heterosexual couples do." P. 91; see also pp. 106, 178-80. At least one commentator has critiqued the notion that heterosexuals, gays, and lesbians define "sex" the same way. Marilyn Frye, Lesbian "Sex," in AN INTIMATE WILDERNESS, supra note 89, at 1.

147. P. 91.

148. P. 21.

149. See, e.g., Philip Blumstein \& Pepper Schwartz, American Couples 191-267 (1983); JoAnn Loulan, Lesbian Passion (1987); JoAnn Loulan, Lesbian Sex (1984); RobSON, supra note 56, at 47-57 (detailing the legal effect of particular activities).

150. P. 42 (fellatio and passive sodomy discussed along with "lesbianism"); p. 43 (anal intercourse compared to interfemoral intercourse- "ejaculating between the boy's thighs"); p. 41 (Athenian homes had statues of Hermes with an erect penis); p. 65 (macho cultures do not abhor anal intercourse); pp. 114-15 (receptive vs. penetrating anal sex).

151. P. 179.

152. P. 299.

153. P. 137.

154. P. 153.

155. P. 137. 
occurrence does not indicate that this phenomenon is a matter of choice rather than biology. Moreover, a recent study of lesbian twins suggests that "[g]enes play a key role in determining the sexual preference of lesbians."156

In any case, the evidence on the causes of sexual orientation is inconclusive. For example, Simon LeVay found purported differences between the brains of gay males and heterosexual males. But he relied on comparisons of the brains of six presumed heterosexual women, nineteen gay men, and sixteen heterosexual men. ${ }^{157}$ LeVay presumed fourteen of the "heterosexual" men and all of the women were heterosexual because he lacked information to the contrary. ${ }^{158}$ Moreover, all of the gay men died of AIDS, compared to only six of the "heterosexual" men. ${ }^{159}$ Finally, even if his findings are replicable, they say nothing about the genesis of lesbianism (or female heterosexuality) because there was no control lesbian group, and the "heterosexual" women were merely presumed heterosexual because LeVay lacked data.

Posner's simplistic view of lesbianism as a choice rather than a predisposition highlights his uncritical reliance on questionable sociobiological theory. Unlike Posner, I am unwilling to put my eggs in either the choice or the biology basket. As a lesbian I follow the debate closely for both personal and political reasons. If gay people are born rather than made, then we likely will be a suspect class entitled to strict scrutiny of legal disabilities. Absent a doctrinal change, then, most legal disabilities would be invalidated as unconstitutional. ${ }^{160}$ On the other hand, if sexual orientation is genetically identifiable, I expect that we will face the genocidal threat of heterosexist parents aborting or altering gay fetuses. As one commentator has said, "[s]ome will say society could 'cure' or 'fix' gays if we just tweak this chromosome or zap that cell."161 Because I would choose to be lesbian if I wasn't born this way, I would rather not give parents, medical science, or the state that homogenizing opportunity.

\section{Psychosomatic discrimination.}

Posner also believes that lesbians are not, and have never been, persecuted on the basis of their sexual orientation. He asserts that the ancient Greeks, ${ }^{162}$ the English, ${ }^{163}$ and the Nazis ${ }^{164}$ did not criminalize lesbian sex.

156. Lesbians Genes Key to Sex Preferences, Denv. Post, Sept. 16, 1992, at 20A.

157. Charlene Crabb, Are Some Men Born to Be Homosexual? What New Research into the Brain has Found, U.S. NEwS \& WORLD REP., Sept. 9, 1991, at 58.

158. Id.

159. Id.

160. See John Cary Sims, Moving Toward Equal Treatment of Homosexuals, 23 PAC. L.J. $1543,1562,1565$ (1992).

161. Crabb, supra note 157, at 58 (quoting a spokesperson for the National Gay and Lesbian Taskforce).

162. P. 70.

163. P. 70.

164. P. 70. In describing the Nazis' sexual agenda, Posner states: "Apart from the failure to take any measures to repress lesbianism, the [Nazi eugenics] program can be seen as a coherent effort to promote the Nazi goal of creating a large master race." P. 59; see also p. 59 n.49 ("There were no laws against lesbianism."). Posner states that in light of the Nazi pronatalist policies aimed at creat- 
He does concede that the ancient Greeks viewed lesbianism as "obscene" and "disgusting" and that it has been "almost everywhere abhorred."165 Nevertheless, Posner states that lesbianism is not criminally or socially sanctioned because heterosexual men "find lesbianism less disgusting than male homosexuality"-a heterosexual man can imagine himself attracted to a lesbian more readily than to a gay man. ${ }^{166}$

Posner implies that lesbians are not discriminated against on the basis of their sexual orientation because lesbians are generally more creative and professionally successful than heterosexual women. ${ }^{167}$ While few lesbians are as successful as Posner's examples, Virginia Woolf and Gertrude Stein, lesbians on average obtain a higher level of education than similarly situated heterosexual women. ${ }^{168}$ The education level of lesbians, however, may be more indicative of rational choice than a lack of discrimination: A lesbian likely does not have access to a man's income and thus must rely on her own earning potential (and perhaps that of another woman) to maintain the lifestyle she desires.

Contrary to Posner's beliefs, the legal and social persecution of lesbians has been extensively documented. ${ }^{169}$ These persecutions have included beatings, banishment, and executions. ${ }^{170}$ Most surprising is Posner's assertion that, because heterosexual men objectify lesbians but not gay men, lesbians are less oppressed than gay men. ${ }^{171}$ To the contrary, lesbians bear a dual

ing a large Aryan nation, "[t]he Nazis should have worried more about lesbians than about male homosexuals, but in fact imposed no penalties on lesbians." P. 194.

165. P. 70.

166. P. 300 .

167. He states:

The fact that lesbians, who are the opposite of effeminate, also seem, like male homosexuals, disproportionately creative (Gertrude Stein and Virginia Woolf are famous examples) is evidence against the effeminacy thesis, although an alternative explanation is that, until recently, married women were unlikely to have a career, and lesbians are presumably a disproportionate fraction of all unmarried women.

Pp. 304-05. Posner falls into the trap (common also to feminists) of presuming that women are all white and middle class and thus, if married, did not work outside of the home until recently. See Elizabeth V. Spelman, Inessential Woman: Problems of Exclusion in Feminist THOUGHT (1988). Moreover, Posner's suggestion that lesbians "are the opposite of effeminate" once again underscores his stereotype of "mannish" lesbians, as discussed in notes 118-120 supra and accompanying text.

168. Approximately $60 \%$ of gay men and lesbians have college degrees, compared to $20 \%$ of the general population. Georgia Dullea, With Varying Degrees of Openness, More Companies Lure Gay Dollars, N.Y. TimEs, Mar. 2, 1992, at D9. More specifically, 32\% of lesbians have undergraduate degrees and $25.6 \%$ have graduate degrees. Overlooked Opinions, Inc., The Gay Market, Jan. 1, 1992 (survey of 7,500 gay men and lesbians) (on file with the Stanford Law Review). In comparison, 20.3\% of the general population has a college degree. Donnelley Marketing, Inc., 1990 Census (data culled from 1990 Census) (on file with the Stanford Law Review).

169. See note 68 supra.

170. In the United States, the New Haven Colony prescribed the death penalty for lesbians as early as 1656 . Rich, supra note 2. During World War II, lesbians were arrested, tried, and sentenced for treason by Nazi S.S. officers. They were sent to prisoner of war camps, where other prisoners "were promised a bottle of schnapps for every lesbian they 'penetrated." " ROBsON, supra note 56, at 42. "[L]esbians may not have been bearing the pink triangle of the homosexuals ... [but rather] the black triangle of the 'asocials,' as did prostitutes." Id.

171. P. 300 . 
oppressed status as women and as lesbians, and the effect of layered oppression is generally one of increased, rather than decreased, disadvantage. ${ }^{172}$

\section{Fertile Ground for Conflict: Lesbian Parents and Soldiers}

Posner addresses lesbian issues primarily in the contexts of parenting and military service. Throughout the discussion, he continues to rely on his beliefs that lesbians are few in number, that they are lesbian by choice, and that they are not penalized on the basis of their sexual orientation.

\section{Lesbians expecting discrimination.}

Posner gives only lukewarm support to lesbians as parents, ${ }^{173}$ and he believes that all parents, regardless of sexual orientation, should encourage their children to be heterosexual. ${ }^{174}$ Despite his belief that children help cement and stabilize sexual relationships (lesbian as well as heterosexual), ${ }^{175}$ Posner refuses to equate lesbian or gay partnerships with heterosexual partnerships, or to accord them equivalent rights to adopt and raise children. ${ }^{176}$ Posner maintains this dichotomy even though he states that lesbian relationships may be more stable than gay male relationships:

Since there is less sexual strain in a lesbian union, the prospects for stable lesbian marriages are better. ...

172. See Ian Ayres, Fair Driving: Gender and Race Discrimination in Retail Car Negotiations, 104 HARV. L. REV. 817 (1991) (finding that white and African-American men and women receive different deals even though they used the same approach with the car dealers, with African-American women receiving the worst deals, worse in fact than an arithmetic calculation of gender and race would predict, and white men receiving the best deals); see also BARBARA GIDDINGS, WHEN AND WHERE I ENTER: THE IMPACT OF BLACK WOMEN ON RACE AND SEX IN AMERICA 6-7 (1984) (describing "double discrimination" suffered by African-American women as they combat sexism and racism); cf. SPELMAN, supra note 167, at 153 (observing that slaves' subordinate positions seemed "to be so taken for granted by Plato that they are hardly mentioned"). If a culture renders a group invisible, that invisibility does not necessarily indicate that the group does not suffer discrimination.

173. P. 419 ("[ []$t$ is undesirable to have a flat rule against permitting homosexuals to have custody of children or even to adopt them.").

174. P. 419 (believing that a lesbian who wants to raise her child as a lesbian "cannot automatically be assumed to be a fit parent").

175. Pp. 305-06. Posner excludes gay men from the category of parents, because even if gay men could legally adopt, they would not form a stable companionate marriage and family due to the "male taste for variety in sexual partners." Pp. 305-06. The prospects for lesbian marriage, according to Posner, are better because women's low sex drive translates to "less sexual strain in a lesbian union." P. 306.

176. Posner cites a study finding that "'relationship quality' among both male and female homosexual couples is higher than that of cohabiting (but unmarried) heterosexual couples and comparable to that of married couples." P. 307. Posner, however, discredits the study on the grounds that the heterosexuals in the study had been living together longer than the gay and lesbian couples. P. 307.

The average married heterosexual couple had been living together for 52 months, compared to 42 months for the gay male couples, and 43 months for the lesbian couples. P. 307. It is unclear why the heterosexuals' living together a few months longer than the gay and lesbian couples undermines the finding, since the longer term relationships could have increased familiarity and stability, which might contribute to relationship quality. Posner also discounts the findings because the heterosexuals were not living with children, but does not state whether any of the gay and lesbian couples were living with children. P. 307. 
... The overall picture is definitely brighter for lesbians, for in addition to the factors already mentioned, it is simple for a lesbian to become pregnant through artificial insemination, an option not open to the male homosexual. ${ }^{177}$

Posner concedes that lesbians have "a fair amount" of parenting experience, but concludes that much of the literature supporting lesbian and gay parenting is "quite worthless."178 Although Posner cites a study finding that children of lesbian couples have fewer psychiatric problems than children living with single heterosexual mothers, 179 he notes several "limitations" of the study. ${ }^{180}$ Despite these "limitations," he might have concluded from these studies that lesbians are at least as fit to be parents as heterosexuals. Instead, Posner concludes that the findings merely "cast doubt on confident judicial assertions that a homosexual parent is bound to influence a child's sexual orientation or impair a child's psychological health or well-being."181 Perhaps Posner agrees with "judicial assertions" limiting gay parents' rights if in fact the gay parent would influence his or her child to be gay. He makes no objection, however, to heterosexual parents encouraging heterosexuality in their children. ${ }^{182}$

Posner ultimately concedes that the law should not prohibit lesbian parenting. But he reaches this conclusion not because of empirical data on the children of lesbian couples, but because of the practical difficulty of enforcing a heterosexual-only parenting law:

[A] ban on adoption by homosexuals does not guarantee that no child will have a homosexual parent. Many homosexuals, especially female homosexuals, have been married and have had children .... It is impossible as a practical matter to prevent a lesbian couple from having a child, either by artificial insemination or by intercourse with a man willing to give up his paternal rights. Moreover, since the mother is usually given custody of children in the event of divorce, a lesbian who is married, has children, divorces, and is awarded custody of the children may thereafter bring up the children in a lesbian household. ${ }^{183}$

Thus, although Posner does not argue for laws prohibiting gay and lesbian parenting, his discussion indicates a moral preference for heterosexual

177. P. 306.

178. P. 417-18 (noting as an example a mail survey in which gay and lesbian parents were asked to evaluate their relationships with their children, but failing to explain why such a mail survey is "worthless").

Other sections of Sex and Reason suggest that he believes that gays and lesbians are too mentally unstable to study and evaluate rationally their own life experiences. See notes 113-120 \& 125131 supra and accompanying text.

179. P. 418.

180. P. 418 (according to Posner, most of the children were prepubertal (though the ages ranged up to 17) and thus "too young to exhibit a pronounced sexual orientation"; "the study did not compare children being raised by a lesbian couple with children being raised by a heterosexual couple"; and "almost all the children in the lesbian households had had a father in the household for at least the first two years of the child's life").

181. P. 418.

182. See notes $186-188$ infra.

183. P. 417 (citation omitted). 
parenting. ${ }^{184} \mathrm{He}$ cites no studies suggesting that children will suffer ill effects from being raised by a lesbian couple. Yet he implies that lesbian parents are only better than a "totally unsuitable custodian" or "being bounced around from one foster home to another." $185 \mathrm{He}$ essentially argues that despite evidence to the contrary, courts should assume lesbian parents are inferior.

Posner's apparent belief that all parents, heterosexual or gay, should actively encourage their children to be heterosexual presents a double standard. He strongly disapproves of lesbian parents who raise their children to be lesbian or gay, 186 but he encourages heterosexual parents to steer their children toward being heterosexual. In particular, he states: "There is a bare chance that the formation of homosexual preference can be prevented by discouraging gender-nonconforming behavior at its outset (later is too late)."187 He also suggests that this parental rejection of their gay and lesbian children is genetic. ${ }^{188}$

Posner fails to recognize that parents' attempts to indoctrinate their children into heterosexuality may contribute to their children's suicides. Young gay people are two to three times more likely to attempt suicide than other young people, and 30 percent of teenagers who commit suicide are lesbian or gay. ${ }^{189}$ Suicide is the leading cause of death among gay, lesbian, and bisex-

184. This discussion is similar to his position that sodomy laws should be repealed because they criminalize behavior which, for gay men, is biological, and thus the laws cannot serve as a deterrent. Pp. 309-11.

185. Pp. 419. Posner advocates a case by case analysis where these circumstances would justify allowing adoption by gays. Pp. 419-20. For further discussion and critique of Posner's pragmatic balance between libertarianism and bigotry, see Eskridge, supra note 15, at 344-52 \& nn.56-95.

186. P. 419. Posner evidently believes that it is radical feminists (by whom he apparently means separatists) who encourage lesbian "unions" and lesbian parenting. See p. 63. Separatists are lesbians who decline to "associate with men and/or with heterosexual women and/or with lesbian mothers of male children." MORGAN, supra note 65, at 710. Posner quotes a school of lesbian thought which argues: "'[O]ur children are the daughters of women who love women over men. Daughters of lesbians, like freedom fighters everywhere, need to be enlisted in infancy, and protected against heterofemininity by words and actions." " P. 419 (citing Baba Copper, The Radical Potential in Lesbian Parenting of Daughters, in Polrtics of Mothering: A Lesbian PARENTING ANTHOLoGY 233, 239 (Sandra Pollock \& Jeanne Vaughn eds., 1987)). Posner adds that "[a] woman who believes this and acts on the belief cannot automatically be assumed to be a fit parent." P. 419 .

In addition, separatists are not the only ones who encourage lesbian unions. At least six religious denominations recognize and perform same-sex marriage ceremonies, called union ceremonies: Unitarian, United Methodist, Quaker meetings, Reform and Reconstruction Judaism, Episcopalianism, and the Metropolitan Community Church. BECKY BUTLER, CEREMONIES OF THE HEART 41 (1991). For additional discussion of lesbian and gay union ceremonies, see id. at 3-45; SuzANNE Sherman, Lesbian and Gay Marriage: Private Commitments, Public Ceremonies (1992).

187. Pp. 308-09 (emphasis in original). Posner continues: 'By condoning 'sissyish' behavior in infancy, a parent may make it difficult for a little boy to become properly boyish in adolescence, and ... he may find it impossible to develop a style, a personality, attractive to girls." P. 309. Although Posner claims in a footnote that he is not "suggesting that "we must, if we can, instill in children the feelings of revulsion [for homosexuality] that guide them to the normal path,' " p. 309 n.47 (citation omitted), his protestation seems disingenuous in light of his other comments.

188. Pp. 102-04. Posner takes note of a theory that "the strong antipathy of most parents toward a child's turning out to be homosexual suggests that homosexuality rarely if ever promotes inclusive fitness." P. 102. Posner defines "inclusive fitness" to mean "the survival not of a particular individual ... but of a particular gene." P. 102 n.38; notes 100-101 supra.

189. Gibson, supra note 97 , at 3-110. 
ual youth. ${ }^{190}$ Parental rejection, which may include physical and verbal abuse and kicking the child out of the home, contributes to the despair which causes suicide. 191 Gay teen suicide is also fueled by "derisive stereotypes of lesbians who are like men and gay men who are like women."192 The stereotype that gays are unhappy and self-destructive inflicts even more damage. It "creates a strong negative context for the early identity formation of young gay males and lesbians, effectively socializing them into suicidal feelings and behavior." 193 Posner's stereotypes are not only inaccurate and insulting, they are life-threatening to gay youth. Together with Posner's double standard (that parents should encourage heterosexuality but discourage homosexuality in children), these factors reveal a position entrenched in moral righteousness, not "moral indifference."

\section{We're in the army now.}

Posner's discussion of lesbians in the military highlights the inaccuracy of his information regarding discrimination against lesbians. Again, Posner relies on stereotypes rather than facts. For example, Posner believes that lesbians are well-suited for the military because of their mannish traits. ${ }^{194}$ He does concede that the risk of sexual harassment and "sexual intrigue" within the armed forces is no more likely to occur among gays than heterosexuals, ${ }^{195}$ so that these factors do not justify exclusion of lesbians from the military. Posner concludes, however, that any persecution against lesbians in the military is exaggerated, since "for the most part they are accepted, generally without fuss."196

This assertion completely ignores the $\$ 27$ million that the military spends annually to discharge 1500 gays and lesbians from its ranks. ${ }^{197}$ One would expect an economic theorist such as Posner to recognize at least the economic impact of such prosecutions. He also ignores the devastating effect of persecution of gays on the morale of all members of the service. ${ }^{198} \mathrm{He}$

190. Id.

191. See id. at 3-112, 3-127.

192. Id. at 3-117. To the extent these stereotypes have any validity, they exist much more when gay men and lesbians first become aware of their identity and are looking for a community. $I d$. at 3-121.

193. Id. at 3-126.

194. P. 315. Posner also asserts that gay men are less suited to military careers than heterosexual men: "the artistic, often effiminate homosexual who is most likely to have a problem of psychological adjustment is least likely to find the military an attractive career." P. 315.

195. P. 316.

196. P. 320.

197. See Anna Quindlen, Homophobia in Uniform, Denv. Post, June 28, 1992, at I4 (basing the \$27 million figure on General Accounting Office statistics); Craig Stoltz, Gays in the Military, DENV. POST, Aug. 7-9, 1992, (Weekend Magazine), at 4-6 (stating that 1,500 military service members are removed each year because of their sexual orientation); see also HUNTER, MICHAELSON \& STODDARD, supra note 106, at 41 (noting that between 1985 and 1989, 6670 enlisted service members and 102 officers were discharged for homosexuality), 43 (adding that nearly \$18 million was wasted on discharging gay men and lesbians in 1984).

198. See Michelle M. Benecke \& Kirstin S. Dodge, Military Women in Nontraditional Job Fields: Causalities of the Armed Forces' War on Homosexuals, 13 HARv. WomEN's L.J. 215 (1990) 
further ignores the potential life-long impact of a dishonorable discharge, which can have the same effect on subsequent employment opportunities as a felony conviction. ${ }^{199}$ Finally, contrary to Posner's assertion that lesbians are less discriminated against than gay men, lesbians are more likely than gay men to be subject to these prosecutions. 200

Posner's claim that lesbians are more accepted than gay men simply does not correspond to reality in the military. One commentator aptly described the process of prosecuting lesbians in the military as a "witch hunt."201 For example, in 1986-1988, the military interrogated almost half of the 246 women at the Parris Island training depot about their sexual orientation, causing many of them to resign rather than endure further investigation. ${ }^{202}$ As a result of the investigation, the military discharged twenty-seven women; three more women received prison sentences, salary forfeitures, reductions in rank, and dishonorable discharges. One woman served 226 days in prison prior to the reversal of her conviction. The reversal was based on two court martial members' participation in the investigation. ${ }^{203}$ Moreover, the military persecuted not only women suspected of being lesbians, but also those who supported the women. In one case, the military relieved from duty the people who testified in the defendant's favor, and urged potential witnesses not to testify. ${ }^{204}$ These rigorous investigations, and the penalties imposed for mere sympathy with the women prosecuted, contradict Posner's analysis by showing that the military does, in fact, make quite a fuss about lesbians in its ranks.

\section{WHEN GoOd Things HAPPEN TO BAD TheORY: AN Alternative CONCLUSION}

Posner explicitly negates lesbian existence, identity, and experience by arguing that lesbians are rare, are lesbian by choice rather than biology, and suffer little discrimination. His theory, based largely on men, ignores women's perspectives and elevates bigotry to scholarship. Its weakness, how-

(stating that service women working in nontraditional jobs who are in good shape, or, especially, who rebuff sexual advances of service men are often targeted as lesbians).

199. ROBSON, supra note 56, at 93-94 ("Any employment with a governmental agency is unlikely and often prohibited, including with agencies unrelated to the military such as the post office, school systems, and public libraries. Many private companies will also refuse to employ anyone dishonorably discharged."). Recent changes make some of the discharges for sexual orientation honorable, rather than dishonorable. Id. at 94 . The discharge, however, must still be explained to subsequent employers.

200. Although women make up only $10 \%$ of military personnel, women accounted for $23 \%$ of the 16,919 discharges for homosexuality between 1980 and 1990 . Stoltz, supra note 197, at 5; cf. HUNTER, Michaelson \& STODDARD, supra note 106, at 42 (indicating that between 1984 and 1989, Marine Corps enlisted women were seven times more likely than their male counterparts to be discharged for homosexuality and that women were twice as likely as men to be discharged for homosexuality in other branches).

201. RoBSON, supra note 56, at 93.

202. Id.

203. Id. Two hundred and twenty-six days in a jail cell is hardly psychosomatic discrimination.

204. Id. 
ever, lies not only in its bias, but also in its malleability. One can easily apply the logic of his theory, absent Posner's biases, to reach the opposite conclusion. Analyzing Posner's conception of women, his belief that certain behaviors, if evolutionarily desirable, are "natural," and his understanding of lesbianism, one could conclude that women are "naturally" lesbian. Thus, Posner's conclusions are arbitrary-a person with different beliefs could use Posner's bioeconomic theory of sexuality to increase lesbian visibility and recognition in the legal culture.

\section{A. Posner on Women}

Posner says very little about women from women's perspectives, focusing instead on men's perceptions and regulations of women's sexuality. $\mathrm{He}$ argues that women have a lower sex drive than men, and that women want companionship whereas men want sex (preferably heterosexual sex, but gay sex if there is no alternative). ${ }^{205} \mathrm{He}$ also claims that women have heterosexual sex to encourage men to "stay around" and protect them and their children. ${ }^{206}$ This presumption of heterosexuality informs Posner's premise that there are very few lesbians or gay men, and that the populations most demographers would characterize as bisexual, are "opportunistic" homosexuals, and therefore really heterosexual.207 If, as my reading of Posner suggests, women are uninterested in heterosexual sex, but potentially interested in companionship and in protection against the violence of other men, the question arises whether heterosexual companionship and protection are, in reality, beneficial to women.

Posner's theory does not suggest that, in fact, men make better companions, protectors, or sexual partners. Indeed, he himself provides ample support for a contradictory view. First, Posner makes as strong an argument as any radical feminist that men are selfish, domineering brutes. According to him, men perceive women as perpetually sexually available to men, ${ }^{208}$ apparently without any ability to refuse sexual relations. ${ }^{209}$ Moreover, Posner assumes that "[a] man wants assurance that the child he is supporting is his own, and he is denied that assurance if his wife is adulterous."210 Men are

205. Pp. 91-98.

206. P. 97.

207. Pp. $105-06$.

208. Posner states:

The continuous sexual availability of the human female, for example, is not an imperative of procreation, since women are fertile only a few days each month; its biological function, rather, is to bind the male to the female so that he will be more likely to protect her and her P. 227. offspring.

209. Posner opines that "[m]arried men and men with steady girlfriends have all the 'normal' sex they want, at home, more or less for free," and therefore are less likely to seek such sex from prostitutes. P. 132. Apparently, Posner does not recognize the consent of wives and steady girlfriends to sexual activity as a cost. Moreover, if men are more sexual than women, and men "get all the 'normal' sex they want," then some of this "normal" sex must be nonconsensual for women.

210. P. 184. Posner concludes that a double standard penalizing adultery by a woman, but not by a man, is economically efficient because the man's cost is measured in terms of supporting a child that is not his, pp. 184-85, while the woman's cost is "merely some diminution in the resources 
therefore overwhelmingly and genetically sexually jealous, since "[h]uman emotions are adapted to the conditions that prevailed during the evolutionary period of human prehistory."211 Under this reasoning, women are not sexually jealous because they are not as sexual as men. ${ }^{212}$ Thus, in his view, male sexual jealousy (which is genetic) and the attendant need to control a female sexual partner dominate heterosexual relationships. ${ }^{213}$ If Posner is correct, men are unpleasant and even oppressive companions.

Second, not only do Posner's heterosexual women lack any choice about when to have sex, but when they do have sex, the sex itself is unlikely to be physically satisfying. Clitoral stimulation is the method by which many women reach orgasm, ${ }^{214}$ and, as Posner acknowledges, "sexual intercourse is a clumsy method of bringing the clitoris to orgasm compared to simple manual stimulation."215 Yet Posner conceives of heterosexual sex as penile-vaginal penetration. 216 Thus, Posner's conception of heterosexual sex as primarily intercourse is in large part inconsistent with female orgasm, or female sexual pleasure. Moreover, it emphasizes procreative sex, a disadvantage to women, since, as Posner recognizes, women who become pregnant subject themselves to an even greater measure of male authority. ${ }^{217}$

Finally, under Posner's theory, men are not only controlling companions and selfish sexual partners, but also too often abusive in their relationships. Although Posner thinks women and their children need male protection

available to support her and her children." P. 184. He does not explain why many women expend resources on step-children.

Contrary to Posner's premise that fathers are obsessed with expending resources only on their own genetic descendants, many cultures link fathering responsibilities to social, rather than genetic ties. See Marc J. Scwartz \& David K. Jordan, ANThropology: Perspective on Humanity 559-63 (1976). For example, the Todas of southern India have a system of polyandry: a woman marries a man and all of his brothers simultaneously. These men are interchangeably known as the father of her children. Id. at 562.

Moreover, studies do not support Posner's premise that men are more sexually jealous than women; in fact the contrary may be true. BLUMSTEIN \& ScHWARTZ, supra note 149, at 261 (comparing men and women's emotional reaction to a threatened affair by their partner, and finding women more troubled by the idea of unfaithfulness than their male partners).

211. P. 185. Posner cites no authority for this position.

212. P. 184 (arguing that women have much lower "costs," or losses, when her male partner has an affair); see also p. 91 ("[W]omen do in fact have ... a weaker sex drive than men.") (citation omitted). Posner never explains why a shrinking of paternal resources, out of which the male partner provides for his female partner and their children, should not provoke "rational" jealousy in women.

213. Pp. $88-98$.

214. See, e.g., Boston Women's Health Book Collective, The New OuR Bodies, OuRSELVES 210 (1992) (noting that "[i]n the late 1960s, sex researchers found that for all women all orgasms depend at least in part on clitoral stimulation, although some women respond to internal pressure as well") (emphasis in original). Penile penetration gives only indirect stimulation to the clitoris, so that "[a]s women begin to explore love making beyond vagina-to-penis intercourse, it is likely that more of us will orgasm more often with our partners." Id.

215. P. 21.

216. Pp. 85-110. Posner's focus on nonreproductive sex only when a woman is not available implies that when a woman is available the heterosexual sex will involve potentially procreative activities.

217. Pp. 54-55 (referring to "continual pregnancy" as a "debilitating and vulnerable state" which entails "submiss[ion] to male authority"); pp. 268-69 (noting that wives' economic dependence on their husbands is "apt to be greater the more children the couple has"). 
from other men, his portrayal suggests that women need protection from their male companions as much as from male strangers. ${ }^{218}$ For example, he asserts that rape and child molestation (which victimize women and children, whom Posner's man is purportedly protecting) is "the situational or opportunistic response of men who are socially or sexually inadequate."219 Thus, rape in Posner's theory is a substitute for consensual sex, rather than an expression of hostility to women. ${ }^{220}$ Men are apparently driven to these behaviors by their "overmastering male sex drive."221 Many of these sexual abuses occur within the family. ${ }^{222}$ Posner himself acknowledges that a significant percentage of rapes are perpetrated by husbands or ex-husbands on their wives, and these assaults cause long term emotional and psychological effects even more devastating than those due to stranger rape. ${ }^{223}$ Most women fear and many actually experience marital or date rape. ${ }^{224}$ Many women also suffer physical abuse by boyfriends and husbands. ${ }^{225}$ This portrait of men as sex starved creatures who must find outlets for their physical needs at all costs tips the scale in favor of women as companions, rather than men. Therefore, women need protection from their male mates, rather than from other men vying for reproductive opportunities, as Posner posits was the case in the evolutionary era.

In Posner's world, then, women could rationally choose other women, over men, for partners. If men make neither good companions nor protectors, and sexual relations with men are not particularly satisfying (and risky in terms of pregnancy), women should logically choose to be lesbian rather than heterosexual. Since Posner believes that sexual behavior is rational (i.e., people make sexual choices based on an appropriate, though perhaps unconscious, response to incentives), women should respond to this situation by becoming lesbian.

218. MAcKINNON, supra note 30, at 41 (1987) (noting that one quarter to one third of women are battered by husbands or boyfriends).

219. P. 107. Posner also argues that rape, at least to some extent, is "natural": "Given the female propensity to ration sexual access, we would expect natural selection in favor of some degree of male sexual aggressiveness." P. 107.

220. P. 370.

221. P. 99.

222. Pp. $399-401$.

223. Pp. 390-91.

224. See Margo T. Gordon \& Stephanie Riger, The Female Fear 2 (1989) (noting that two thirds of women do not feel safe walking in their own neighborhoods, and that the only crime women fear more than rape is murder); CATHARINE A. MACKINNON, TowARD A FEMINIST THEORY OF THE STATE 149 (1989) ("Given the statistical realities, all women live all the time under the shadow of the threat of sexual abuse.").

225. At least one out of 26 , or 1.8 million American women are beaten each year by their husbands or male companions. See The ABusive PARTNER: AN ANAlysis of DoMestic BatTERY 9 (Maria Roy ed., 1982). Moreover, domestic violence is the single largest cause of injury to women in the United States-injuring more women than mugging, motor accidents, or rape. The FBI estimates that fully $50 \%$ of American women will be assaulted at least once by an intimate adult partner. Human Services Roundtable, Domestic Violence: A Community Responds 5 (Fall 1992) (on file with the Stanford Law Review). Although there is no conclusive data on the rate of battery in the lesbian community, preliminary studies suggest that it might be less prevalent than heterosexual battery, or at least less physical. See RENZETTI, supra note 97, at 17-19. 


\section{B. It's Only Natural}

Posner asserts that heterosexuality is "natural" and "normal" while homosexuality is "deviant." 226 He reasons:

It is not absurd ... to argue that we have been given a set of organs whose function is procreation and that to use them in some other way, for example in conjunction with organs such as the anus that do not have a procreative function, is contrary to nature's plan. ${ }^{227}$

I have already contended that choosing lesbianism in Posner's world might be rational. One could also argue, accepting Posner's brand of essentialism, that lesbianism is "natural" in light of women's bodies. Essentialism is the premise that certain behaviors or characteristics are "natural," "normal," or inherent to a group or members of a group. ${ }^{228}$ Although rationality and essentialism may seem mutually exclusive in that rationality emphasizes choice and essentialism emphasizes essence, Posner's analysis suggests that the two are, in fact, complementary. What is natural undergirds what is rational. Economics emphasizes rationality and choice, and biology, in Posner's theory, "explain[s] the drives and preferences that establish the perceived benefits of different sexual practices to different people."229 In short, Posner believes that biological urges, the very essence of human sexuality, demand sexual choices to satisfy those urges. He implies that people are heterosexual because, given the external incentives, it is rational. ${ }^{230}$

In Posner's view, "nature" is a manager supervising the genetic fitness of men and women, her putative employees. Body organs have certain "natural" uses and the natural use of procreative organs is procreation. For example, a man who uses his penis-a procreative organ-for nonprocreative activities such as anal sex is acting "contrary to nature's plan."231 But Posner also posits that activities such as masturbation and homosexuality are also nature's way of managing competition among men for women, ${ }^{232}$ and are thus substitutes for heterosexual intercourse. ${ }^{233}$

Applying Posner's theory to women, however, one finds that women's primary organ for achieving sexual satisfaction, the clitoris, is unrelated to Posner's notion of heterosexual sex. Thus, the clitoris is "an embarrassment

226. See, e.g., pp. 88-108 (normal v. deviant sex); p. 220 ("normal masculine development"); p. 292 ("normal appearing" gay men). Posner also contrasts "normal" or ordinary sex with "kinky sex" in arguing that contemporary prostitutes specialize in kinky sex. Posner does not define what distinguishes "normal" from "kinky" sex. P. 132.

227. Pp. 226-27.

228. See SPELMAN, supra note 167 , at 159 (defining essentialism as the tendency to "take what I understand to be true of me 'as a woman' for some golden nugget of womanness all women have as women ... [which] makes the participation of other women inessential to the production of the story. How lovely: the many turn out to be one, and the one that they are is me.").

229. P. 7.

230. See p. 85 ("Responding appropriately to incentives, whether consciously or not, is rational").

231. P. 227.

232. P. 227.

233. Pp. 99, 106 (including exhibitionism, pedophelia, and rape as substitute methods of sexual gratification). 
to the idea that all sexual organs are specialized to reproduction."234 One could argue that if nature had an "intended use" for all body parts, then "nature" must have intended that women's sexuality and reproduction be separate, rather than intertwined. ${ }^{235}$ Separating female sexuality from reproduction also makes sense when one considers the impact of procreation on women. As Posner notes, women's occupational and sexual choices depend on the number of children they bear and raise. ${ }^{236}$ Therefore, women have an incentive to procreate selectively, rather than risk conception with every sexual encounter. A rational examination of both nature and other incentives implies that women should opt to enjoy companionship and sex with other women, and only occasionally have sex with men for purposes of reproduction.

Reversing the status of lesbianism from "deviant" to "natural" is not a novel concept. Some commentators have posed the question of female sexuality in the reverse of Posner's form: What makes women heterosexual, rather than lesbian? ${ }^{237}$ They argue that since women have been traditionally responsible for child-rearing, children of both sexes initially bond with the mother. As a boy matures, he separates from this powerful, nurturing figure with great anguish, achieving the separation only by designating her as "other" and despising her for depriving him of their former closeness. ${ }^{238}$ Sexism is caused by men's failure to resolve the conflict of intimacy and individuation, which leads many men to hate women as lost love objects. ${ }^{239}$ A young girl, in contrast, recognizes the similarity between herself and her mother, and does not individuate from her mother as a boy would. ${ }^{240}$ One wonders, then, what would make any girl or young woman turn against her nurturing mother for the elusive and abusive attention of Posner's man? A lesbian would appear to be the natural outcome.

Adrienne Rich analyzed the presumption of female heterosexuality in her ground-breaking essay, Compulsory Heterosexuality. There, she argued that all women are part of the "lesbian continuum," which includes a range of woman-identified experience beyond female-to-female sexual contact: "the sharing of a rich inner life, the bonding against male tyranny, the giving and

234. P. 227.

235. Cf. KINSEY ET AL., supra note 134, at 467 (finding that women experience orgasm more frequently in lesbian than in heterosexual contacts).

236. Pp. 268-69. Posner states:

[M] uch of the variance in sexual behavior and customs across cultures and eras is explained by a handful of factors, ... above all, the changing occupational role of women. That changing role is, in turn, a function of infant mortality, the value of children, the technology of contraception, the existence of labor-saving devices in household production ... and the degree to which well-remunerated work not requiring great physical strength or stamina is available in the economy.

P. 86.

237. See, e.g., Rich, supra note 2.

238. Nancy Chodorow, Family Structure and Feminine Personality, in Woman, Culture AND SocieTY 43 (Michelle Zimbalist Rosaldo \& Louise Lamphere eds., 1974).

239. Id.

240. Id. 
receiving of practical and political support."241 She also stated that male power perpetuates compulsory heterosexuality, and described several aspects of male power. Three of Rich's observations about male power pertain to a lesbian analysis of Sex and Reason. First, male power attempts to "deny women [their] own sexuality (by means of clitoridectomy and infibulation[,] ... and punishment, including death for female adultery ... and for lesbian sexuality)."242 Second, male power tries to force male sexuality upon women "(by means of rape (including marital rape) and ... the socialization of women to feel that male sex 'drive' amounts to a right)."243 Third, male power withholds from women "large areas of the society's knowledge and cultural attainments (by means of ... the 'Great Silence' regarding women and particularly lesbian existence in history and culture)."244

Posner's theory fits Rich's description of compulsory heterosexuality as a mechanism of male power. First, it denies female sexuality by excising it. Second, it forces male sexuality on women, justified by the "overmastering male sex drive." 245 Third, it erases female and lesbian contributions and experiences from the history and culture of sexuality. Thus, Posner's neglect of lesbians in Sex and Reason is not merely negligent scholarship. It is an exercise of male power through the mechanism of compulsory heterosexuality. In doing so, he enforces "heterosexuality for women as a means of assuring male right of physical, economical, and emotional access."246

Posner, however, is not alone in assuming female heterosexuality; "[t]he lie of compulsory female heterosexuality today afflicts . . . . every relationship or conversation over which it hovers. ... [and] every heterosexual relationship is lived in the queasy strobelight of that lie."247 Because compulsory heterosexuality is a vehicle of male power, the status of lesbianism as "natural" under my reversal of Posner's theory may salvage it. The alternative is for women to be unwilling participants in a theory that not only minimizes, but actually exploits, female sexuality to further male dominance of women.

Finally, Posner states that love is "natural,"248 and that sex cements a love relationship. ${ }^{249}$ In his view, therefore, women naturally form sexual relationships with men to fulfill their need for companionship and protec-

241. Rich, supra note 2, at 192.

242. Id. at 183 .

243. Id. at 183-84.

244. Id. at 184-85. Rich identifies five other characteristics of male power, but these three apply best to my critique of Posner's theory.

245. P. 99.

246. Rich, supra note 2, at 191. Rich continues, "One of many means of enforcement is, of course, the rendering invisible of the lesbian possibility, an engulfed continent that rises fragmentedly to view from time to time only to become submerged again." Id. Posner's treatment of lesbians in Sex and Reason fits this description perfectly: occasional references that are ultimately obscuring, and an underlying assumption that all women are naturally heterosexual.

247. Id. at 199.

248. P. 118 ("Love, then, is natural in a fairly literal sense; where culture enters is in deflecting, sublimating, erasing, or otherwise controlling love.").

249. P. 113 ("Sex cements the bond between mates and by doing so helps ensure that the male will stay around to protect the female and her offspring from hunger and predation."). 
tion. One could easily argue, however, that given a woman's need to protect herself from unwanted reproduction, the abusive nature of Posner's man, and her natural need to form a sexual love relationship, she should logically form sexual relationships with other women, rather than with men.

\section{Surprisel She's a Lesbian!}

Posner never even defines what he means by the term "lesbian." Although one commentator defines lesbian as "a woman who says she is,"250 Posner would likely disagree because he believes that lesbian sexuality is more fluid than male sexuality. Thus, a "woman who says she is" may soon change her mind if offered the appropriate heterosexual incentives. Posner presumes that women are uninterested in sex with men, ${ }^{251}$ but that women naturally want love, sex, and companionship. ${ }^{252}$ Under my reversal of Posner's theory, these needs for love, sex, and companionship can be better met with other women than with men, particularly if women sleep with men solely when they want to reproduce. ${ }^{253}$ Thus, under Posner's theory, women arguably are naturally lesbian.

Posner's beliefs that lesbians are few, are lesbian by choice, and are not subject to discrimination on the basis of their sexual orientation support my reversal of Posner's theory. First, the number of lesbians does not preclude lesbianism from being natural. Posner believes that gay men are far less prevalent in the population than Kinsey and other researchers contend, ${ }^{254}$ but gay male sex is, nevertheless, natural under Posner's theory. ${ }^{255}$ Thus, women may be naturally lesbian under Posner's theory even if they are few in number. Second, Posner's contention that lesbians are made rather than born, regardless of its merit, is tailor made for the conclusion that women are naturally lesbian. If lesbianism is a matter of choice, then all most women would need to make the choice would be a good public relations campaign. Finally, Posner's contention that lesbians are not discriminated against on the basis of sexual orientation similarly supports designating lesbianism as natural under Posner's theory. Disregarding evidence disproving Posner's contention, the lack of discrimination coupled with the benefits of lesbianism in comparison to heterosexuality will lead most women to be lesbian since the benefits are relatively high and the costs relatively low.

Four elements of Posner's theory do pose potential pitfalls with flipping it to conclude that women are naturally lesbian: (1) the possibility of kind men in companionate marriages; (2) the importance of procreation; (3) the low female sex drive; and (4) the possibility of sexual mores changing over

250. RoBSon, supra note 56, at 21 (quoting Cheryl Clarke, Lesbianism, An Act of Resistance, in This BRIDge CAlled MY BaCK: Writings by RAdical Women of Color 128 (Cherrie Moraga \& Gloria Anzaldúa eds., 1983)).

251. See note 48 supra and accompanying text.

252. See notes 53 \& 205-207 supra and accompanying text.

253. See notes 208-249 supra and accompanying text.

254. See note 51 supra.

255. P. 99 (male homosexuality as a "safety valve"). 
time. These factors, however, do not destroy my reversal and rehabilitation of Posner's theory. Although Posner implies that men in companionate marriage are kinder and gentler, thus less likely to drive women to lesbianism, he states early on that these qualities will repel, rather than attract women. ${ }^{256}$ Thus, in Posner's world, these kind gentle men will probably be gay rather than participants in companionate heterosexual marriages. Nor does the centrality of procreation as a sexual motivator doom my rehabilitation of Posner's theory. Posner concedes that the conceptual act takes only minutes to accomplish. ${ }^{257}$ Those minutes do not require a lifetime of living together. Similarly, Posner's belief that women have low sex drives does not defeat my premise, because his argument is really that women have low hetero sex drives. ${ }^{258}$ Given Posner's silence about what women want from sex (other than protection and companionship), the possibility of lesbian desire exists between the lines of his text. In the context of compulsory heterosexuality, women may have to construct their lesbian desire once they become aware of the possibility of lesbian existence. ${ }^{259}$ Finally, even Posner's apparent openness to changing sexual mores does not defeat my rehabilitation of his theory, because Posner states that human emotions conform to the conditions that prevailed in the evolutionary era of human prehistory. ${ }^{260}$ Thus, it is unclear to what extent men will retain their paleolithic emotions despite social changes to benefit women.

\section{Conclusion: The Joy of Resistance}

Posner combines sociobiology and economics to craft a bioeconomic theory of sexuality. His theory is flawed because he fails to adequately take into account the experience of anyone other than white heterosexual men. His negation of lesbians' existence, identity, and experience exemplifies this limited focus. In particular, Posner believes: (1) lesbians are few in number; (2) they are lesbian by choice rather than by disposition; and (3) they do not suffer discrimination on the basis of their sexual orientation.

Paradoxically, these bioeconomic premises of Sex and Reason can lead to a conclusion which contradicts Posner's. In my reversal and rehabilitation of Posner's theory, the cost of a sexual relationship with a man is outweighed by the benefits of a lesbian relationship. Thus, Posner's bioeconomic theory of sexuality could support the conclusion that women are naturally lesbian. Posner's theory is flawed because it supports both his argument that heterosexuality is natural and my argument that lesbianism is natural. This flaw is not surprising, given Posner's reliance on questionable premises of sociobi-

256. P. 93 (women are attracted to strong, aggressive men who can protect them and their children).

257. P. 90.

258. P. 90-98 (women prefer companionship over (heterosexual) sex). But see p. 91 (lesbians "have intercourse less frequently, on average, than heterosexual couples") (offered to support premise that women, not lesbians in particular, have low sex drives compared to men generally).

259. See notes 241-247 supra.

260. P. 185. 
ology, and his moral dogma negating or vilifying lesbianism, despite his pretense of "moral indifference."

Posner states that his "book cannot be an end but only a beginning."261 The beginning of an inclusive discourse on sexuality would take into account the existence, identity, and experiences of lesbians and others slighted by Posner's bioeconomic theory of sexuality. The sociobiological premises and moral judgments that warp his portrayal of lesbians also warp and negate women generally, not to mention African-Americans and poor people. Until Posner's theory can accommodate the sexuality experienced by humans other than middle and upper class heterosexual white men, it will remain fatally exclusive. If Posner can only explain male sex, his theory cannot be complete or even valid. Posner could start by acknowledging that the costs and benefits of a heterosexual or gay relationship differ depending on one's perspective, and are not limited to two-dimensional stereotypes. Perhaps then he would begin to find room in his theory for a broader range sexuality.

In Possessing the Secret of Joy, Tashi experiences the mutilation of her sexual organs as an excision of her sexuality. ${ }^{262}$ She ultimately discovers that one secret of joy remains: an act of resistance against the one who mutilated her. ${ }^{263}$ Likewise, the only secret of joy remaining after Posner's excision of lesbian sexuality is the similar joy of resistance.

261. P. 439.

262. Besides experiencing extreme discomfort in urination and her menstrual periods, and no longer being able to walk other than with a shuffle, WALKER, supra note 1 , at 59 , Tashi could not enjoy sexual relations with her husband. When she finally conceived, he grimly said it must be an immaculate conception, for they had tried unsuccessfully to have intercourse for three months: "each time he touched me I bled. Each time he moved against me I winced. There was nothing he could do to me that did not hurt." Id. at 64 .

263. Id. at 279. 